\title{
The 27 May 1937 catastrophic flow failure of gold tailings at Tlalpujahua, Michoacán, Mexico
}

\author{
J. L. Macíass ${ }^{1}$, P. Corona-Chávez ${ }^{2}$, J. M. Sanchéz-Núñez ${ }^{3}$, M. Martínez-Medina ${ }^{4,5}$, V. H. Garduño-Monroy ${ }^{2}$, \\ L. Capra ${ }^{6}$, F. García-Tenorio ${ }^{1}$, and G. Cisneros-Máximo ${ }^{1}$ \\ ${ }^{1}$ Instituto de Geofísica, Unidad Michoacán, Universidad Nacional Autónoma de México, Campus-Morelia, Morelia, 58090, \\ Michoacán, Mexico \\ ${ }^{2}$ Instituto de Investigaciones en Ciencias de la Tierra, Universidad Michoacana de San Nicolás de Hidalgo, Morelia, \\ 58040, Michoacán, Mexico \\ ${ }^{3}$ Instituto Politécnico Nacional-CIIEMAD. Miguel Othón de Mendizabal s/n. Col. La Escalera., 07320, Distrito Federal, \\ Mexico \\ ${ }^{4}$ Maestría en Geociencias y Planificación del Territorio, Universidad Michoacana de San Nicolás de Hidalgo, Morelia, \\ 58040, Michoacán, Mexico \\ ${ }^{5}$ Instituto Nacional de Estadística Geografía e Informática, Centro de Información Michoacán, 58130, Morelia, \\ Michoacán, Mexico \\ ${ }^{6}$ Centro de Geociencias, Universidad Nacional Autónoma de México, Campus-Juriquilla, Querétaro, 76230, Mexico
}

Correspondence to: J. L. Macías (macias@geofisica.unam.mx)

Received: 16 June 2014 - Published in Nat. Hazards Earth Syst. Sci. Discuss.: 20 August 2014

Revised: 27 April 2015 - Accepted: 4 May 2015 - Published: 27 May 2015

\begin{abstract}
On 27 May 1937, after one week of sustained heavy rainfall, a voluminous flood caused the death of at least 300 people and the destruction of the historic El Carmen church and several neighborhoods in the mining region of Tlalpujahua, Michoacán, central Mexico. This destructive flood was triggered by the breaching of the impoundment of the Los Cedros tailings and the sudden release of circa $16 \mathrm{Mt}$ of water-saturated waste materials. The muddy silty flood, moving at estimated speeds of $20-25 \mathrm{~m} \mathrm{~s}^{-1}$, was channelized along the Dos Estrellas and Tlalpujahua drainages and devastated everything along its flow path. After advancing $2.5 \mathrm{~km}$ downstream, the flood slammed into El Carmen church and surrounding houses at estimated speeds of $\sim 7 \mathrm{~m} \mathrm{~s}^{-1}$, destroying many construction walls and covering the church floor with $\sim 2 \mathrm{~m}$ of mud and debris. Revision of eyewitness accounts and newspaper articles, together with analysis of archived photographic materials, indicated that the flood consisted of three muddy pulses. Stratigraphic relations and granulometric data for selected proximal and distal samples show that the flood behaved as a hyperconcentrated flow along most of its trajectory. A total volume of
\end{abstract}

the Lamas flood deposit was estimated as $1.5 \times 10^{6} \mathrm{~m}^{3}$. The physically based bidimensional (2-D) hydraulic model FLO2D was implemented to reproduce the breached flow $(0.5$ sediment concentration) with a maximum flow discharge of $8000 \mathrm{~m}^{3} \mathrm{~s}^{-1}$ for a total outflow volume (sediment + water) of $2.5 \times 10^{6} \mathrm{~m}^{3}$, similar to the calculations obtained using field measurements.

Even though premonitory signs of possible impoundment failure were reported days before the flood, and people living downstream were alerted, authorities ordered no evacuations or other mitigative actions. The catastrophic flood at Tlalpujahua provides a well-documented, though tragic, example of impoundment breaching of a tailings dam caused by the combined effects of intense rainfall, dam weakness, and inadequate emergency-management protocols - unfortunately an all-too-common case scenario for most of the world's mining regions. 


\section{Introduction}

"Tailings" is the general term for milled waste materials from processing of ore that are successively accumulated during the course of mining activities (Rico et al., 2008b). Such tailings are usually accumulated in upstream/downstream valleys or ring impoundments, and, in all cases, these are retained by an outer dam wall or dyke generally made of wood (Klohn, 1972; Blight, 1997; Sammarco, 2004; Blight and Fourie, 2003). As summarized by Blight and Fourie (2003), if for any reason the dam wall breaks, there is the danger that the settled tailings can escape the impoundment, causing mass movements and/or a flow failure, which commonly results in serious socioeconomic and environmental consequences. Several dam failures have occurred during the past century, with key examples studied in South Africa (Blight et al., 1981; Van Nierkirk and Vlijoen, 2005), Spain (AyalaCarcedo, 2004; Gens and Alonso, 2006), Italy (Genevois and Tecca, 1993; Chandler and Tosatti, 1995; Berti et al., 1997), and Chile (Dobry and Alvarez, 1967). Sammarco (2004) grouped dam breakouts into two categories: (i) failures in which water flows over the tailings causing erosion and transportation of the material progressively deposited downstream (overtopping) and (ii) failures in which liquefaction of the tailings and/or breakout of the dam produces a highly hazardous flow that rushes downhill. Blight and Fourie (2003) documented different types of dam failures from mine tailings and municipal dumps by analyzing a database of 184 cases (US National Committee on Large Dams, 1994). These authors documented at least 22 failures over a period of 72 years (1928 to 2000) that caused 1400 casualties. Rico et al. (2008b) documented 147 cases worldwide of dam tailings failures triggered by 16 different factors, including management operations, seismic liquefaction, rise of the phreatic surface, mass movement slope instability, fluvial undermining, inadequate/insufficient beach or free board, piping/seepage, dam overtopping/overflow, foundation failure, water level rise, snowmelt, inadequate decant pipe construction, unusual rainfall event, insufficient perviousness of filter drain, mine subsidence, and structural failure. However, the most common incidences were caused by unusual rain/snow periods, accounting for as much as $26 \%$ of all factors, or $39 \%$ for a combination of one or two factors (Rico et al., 2008a). As documented by these authors, breaching floods are usually composed of highly water-saturated oozy sediment, which exhibits a wide range of fluid behavior from debris flows to muddy floodwater (Rico et al., 2008a). Considering outflow volume versus runout distance, these authors grouped these floods into two categories: (1) floods with high-viscosity spilled mine waste and (2) floods with large volume of water within the tailings dam (70-85\%) related to heavy rains and dam overtopping. Despite all these data, there is an evident gap between the diversity of the tailings dam characteristics in the world and the relatively few studies documenting them, especially for cases in Latin Amer- ica. Consequently, modern geotechnical, hydrological, and hydraulic studies are critically needed to improve the environmental regulations relevant to safe management of mine wastes.

In this work, we present a well-documented case study of a dam failure on 27 May 1937, caused by a combination of unusual rainfall and breaching of the tailings impoundment that generated a catastrophic flood in the town of Tlalpujahua, Michoacán, central Mexico. Based on eyewitness accounts, information in printed reports, pictures, new results from detailed field survey, and laboratory analyses, we were able to reconstruct the dam breaching, outflow flow dynamics, and the impact on settlements. Finally, numerical simulations were able to mimic the velocities and depths of the flow as observed and calculated in the field.

\section{Data and methods}

We compiled all available information of the Dos Estrellas mining activities as well as the eyewitness accounts, newspapers and printed reports, including the historical and photographic archive of the historic gold tailings flood at Tlalpujahua Michoacán, Mexico. To produce a digital elevation model (DEM) with $10 \times 10 \mathrm{~m}$ resolution, we used the 2007 digital topographic map (scale 1:50000, chart E14A1) from Instituto Nacional de Estadística, Geografía e Informática (INEGI, 2007). Six printed aerial photos $(1: 75000)$ from INEGI; two orthophotos, E14A16E1 and E14A16F1 (scale $1: 37500)$; one panchromatic image $(1: 10000)$; and one SPOT 5 panchromatic satellite image $(2.5 \mathrm{~m} / 10 \mathrm{~m}$ multispectral resolution) were used to build a preliminary map which includes lithological contacts, drainage patterns, and characterization of the tailing dump. The geologic and geographic data of the area were collected and synthesized in a spatial database in the commercial software ArcGIS 9.3 and Erdas 9.3. Fieldwork led to the final map (Fig. 8) accompanied by detailed 23 stratigraphic columns carried out along the tailing flood deposit. From these sections, 14 samples were selected for particle size analysis. Matrix samples were dry-sieved at $1 \varphi$ ranges between -5 and $4 \varphi$, and wet-sieved between 5 and $9 \varphi(31 \mathrm{~mm}-2 \mu \mathrm{m})$, by using the laser fence meter instrument at the Universidad Michoacana de San Nicolás de Hidalgo. The results were normalized to obtain a full-size spectrum (Kellerhals and Bray, 1971). Granulometric statistical parameters (Md $\varphi$ and $\sigma \varphi$ ) were calculated following Inman (1952) and Folk and Ward (1957) (Fig. 9). The cross-section areas of some locations and flow discharges were obtained with the OriginLab program, and the flow simulation was carried out with the 2-D flood modeling software (O'Brien et al., 1993).

\section{Geology and geography}

The mining district of El Oro-Tlalpujahua (MDOT) is located within the states of Michoacán and Mexico and is part 


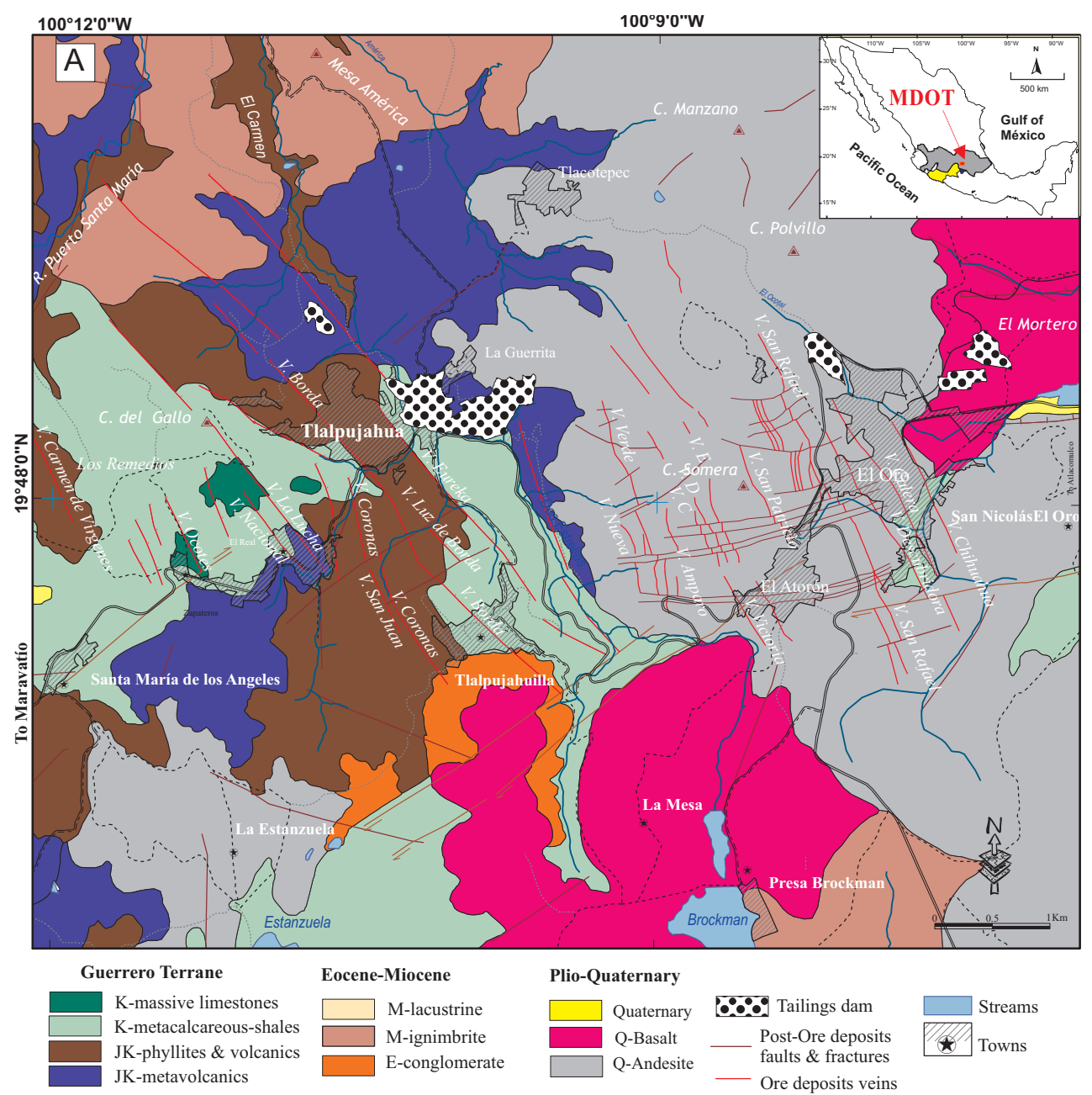

Figure 1. Location of the mining district of El Oro-Tlalpujahua (MDOT) in central Mexico (inset), (a) showing the principal rock types, ore veins, and tailings dams. Geological map of the MDOT from Corona Chávez et al. (2010).

of the hydrological basin of the "Lerma Santiago River", region 12 (Fig. 1). The MDOT is located within the MiocenePliocene Trans-Mexican Volcanic Belt (Gómez-Tuena et al., 2007). However, the MDOT ore deposits are hosted in Jurassic-early-Cretaceous basement rocks (Silva Ortiz and Salgado Soto, 1988; De La Teja Segura, 2000; CentenoGarcía et al., 2003). Even though MDOT is essentially known as a gold deposit, the mineralization in the district is part of an extensive silver metallogenic province (Ostroumov and Corona-Chávez, 1999; Albinson et al., 2001) (Fig. 1). The mineralized structures are hosted in a NW-SE hydrothermal vein system, which has a roughly tabular form, $\sim 3.5 \mathrm{~km}$ in length and with thicknesses varying from 0.5 to $33 \mathrm{~m}$. Au-Ag minerals are essentially hypogenic sulfides and sulfosalts associated with a gangue of calcite and quartz (Flores, 1920; Reiniery, 1955).

Geographically, the MDOT lies within a mountainous area, with average elevations of $2600-3000 \mathrm{~m}$ and moderately steep slopes ranging from 16 to $35^{\circ}$. The morphol- ogy of the MDOT basin ends abruptly to the north because of the active tectonics of the Morelia-Acambay graben system. To the east, the MDOT is adjacent to El Oro region, where monogenetic cinder cones coexist with shallow lacustrine basins containing wetlands. The MDOT has a humid temperate climate, with summer rainfall averaging $900 \mathrm{~mm}$ per year (CNA, 2013; http://www.conagua.gob.mx/; Fig. 2). The driest months are from January to May and November to December with precipitations under $40 \mathrm{~mm}$ (see Fig. 2). The region's annual average temperature varies between 12 and $18^{\circ} \mathrm{C}$, with the lowest in January $\left(\sim 3-18^{\circ} \mathrm{C}\right)$ and higher temperatures during April and May $\left(>22^{\circ} \mathrm{C}\right)$.

\section{Summary of the MDOT development}

Industrial mining in Mexico began during the colonial era, during which the MDOT was known as the "Real de Minas of Tlalpujahua". During this time, a series of exposed veins 


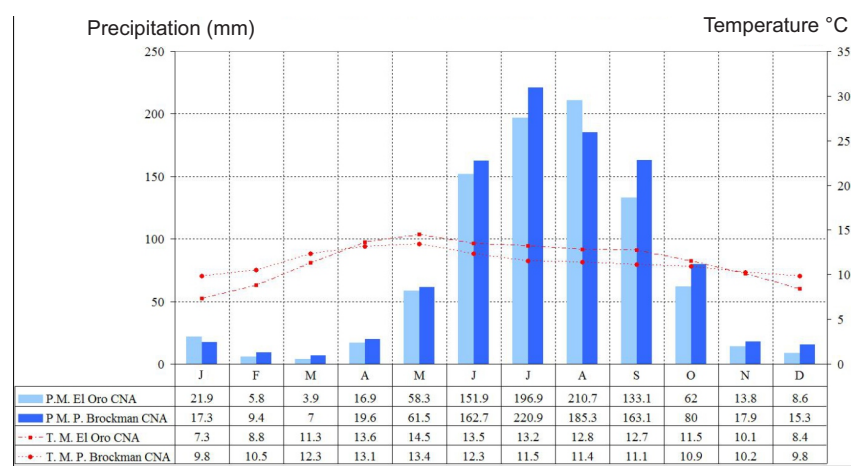

Figure 2. Annual precipitation and temperature data recorded at the meteorological stations in El Oro (15183) and Presa Brockman (15 070) of the Comisión Nacional del Agua (CNA).

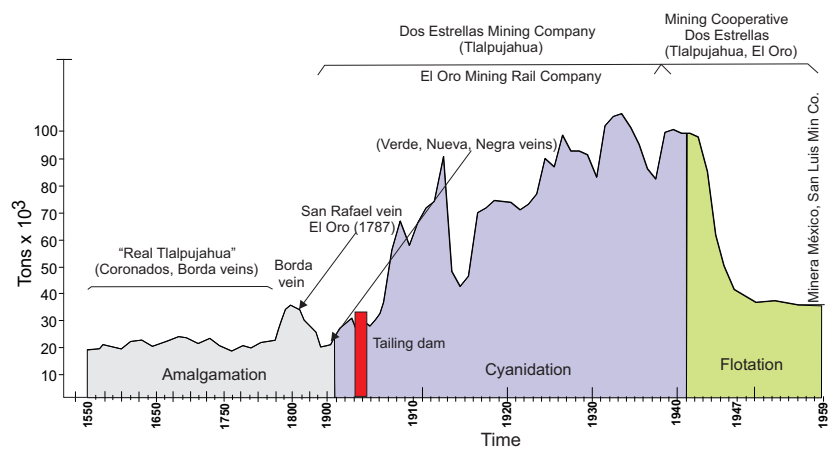

Figure 3. Historical record of the amounts of material extracted by the mining company (1898-1938) and mining cooperative "Dos Estrellas" (1939-1959) and the relationships with the metallurgical processes used (after Uribe Salas, 2008).

were exploited within areas of the present-day cities of El Oro and Tlalpujahua (Fig. 1). During the following centuries (XVI-XX), the mining works were continuous and large, medium, and small mining companies succeeded to create a culture linked to the work of mineral extraction and processing of silver and gold. The largest production period began in the early XIX; since then, the mining activity can be summarized in three periods (Fig. 3): (i) during the first one (1820-1870), the British El Oro Company committed capital and technology towards the rehabilitation of mines that were destroyed or abandoned during the Mexican War of Independence; (ii) in the second one (1898-1938) (Fig. 1b and Table 1), the richest gold veins were discovered under the Cerro Somera and were exploited intensively; and (iii) in the third one (1939-1959) the mining cooperative "Las Dos Estrellas" in El Oro and Tlalpujahua and the Commission of Mining Development started operations (Uribe Salas, 2008, 2009). The towns of Tlalpujahua (XVI century) and El Oro (XVIII century) became increasingly developed with the construction of the mineral separation and metal-casting plants, roads, shafts or pits to access mineral deposits, and accumulation of dumps and mine tailings (Uribe Salas, 2008) (Fig. 1). Many
Table 1. Summary of extracted metals and amount of waste produced at Tlalpujahua.

\begin{tabular}{|c|c|c|c|c|}
\hline Year & Extracted & Silver & Gold & Waste \\
\hline & (tons) & $(\mathrm{kg})$ & $(\mathrm{kg})$ & (tons) \\
\hline \multicolumn{5}{|l|}{1900} \\
\hline 1901 & 22435 & 2000 & 0 & 20435 \\
\hline 1902 & 52722 & 4700 & 1000 & 47022 \\
\hline 1903 & 67305 & 6000 & 1500 & 59805 \\
\hline 1904 & 75157 & 6700 & 2000 & 66457 \\
\hline 1905 & 89740 & 8000 & 2000 & 79740 \\
\hline 1906 & 131133 & 11690 & 2321 & 117122 \\
\hline 1907 & 325309 & 29000 & 3227 & 293082 \\
\hline 1908 & 432000 & 28127 & 3075 & 400798 \\
\hline 1909 & 341111 & 35000 & 5000 & 301111 \\
\hline 1910 & 424198 & 47685 & 6530 & 369983 \\
\hline 1911 & 479723 & 62627 & 6775 & 410321 \\
\hline 1912 & 505000 & 63000 & 6000 & 436000 \\
\hline 1913 & 673053 & 60000 & 4000 & 609053 \\
\hline 1914 & 245664 & 21900 & 1000 & 222764 \\
\hline 1915 & 191820 & 17100 & 4000 & 170720 \\
\hline 1916 & 229959 & 20500 & 4300 & 205159 \\
\hline 1917 & 463655 & 41333 & 5200 & 417122 \\
\hline 1918 & 482354 & 43000 & 5000 & 434354 \\
\hline 1919 & 509770 & 45444 & 4000 & 460326 \\
\hline 1920 & 504789 & 45000 & 3300 & 456489 \\
\hline 1921 & 503533 & 44888 & 3000 & 455645 \\
\hline 1922 & 473313 & 46675 & 2750 & 423888 \\
\hline 1923 & 493857 & 41966 & 2699 & 449192 \\
\hline 1924 & 533772 & 35428 & 2548 & 495796 \\
\hline 1925 & 665316 & 37024 & 2805 & 625487 \\
\hline 1926 & 632056 & 45627 & 2096 & 584333 \\
\hline 1927 & 752198 & 51132 & 2351 & 698715 \\
\hline 1928 & 693460 & 55850 & 2328 & 635282 \\
\hline 1929 & 693257 & 64461 & 1914 & 626882 \\
\hline 1930 & 676962 & 76425 & 2034 & 598503 \\
\hline 1931 & 593835 & 46447 & 1856 & 545532 \\
\hline 1932 & 786936 & 38385 & 1812 & 746739 \\
\hline 1933 & 821645 & 31702 & 1585 & 788358 \\
\hline 1934 & 829663 & 40111 & 2416 & 787136 \\
\hline 1935 & 777759 & 46339 & 2138 & 729282 \\
\hline 1936 & 717755 & 40000 & 2000 & 675755 \\
\hline 1937 & 628129 & 28452 & 1258 & 598419 \\
\hline 1938 & 589275 & - & - & 589275 \\
\hline 1939 & 761431 & - & - & 761431 \\
\hline 1940 & 772083 & - & - & 772083 \\
\hline 1941 & 758148 & - & - & 758148 \\
\hline 1942 & 759625 & - & 1500 & 758125 \\
\hline 1943 & 744709 & - & - & 744709 \\
\hline 1944 & 614713 & - & - & 614713 \\
\hline 1945 & 379183 & - & - & 379183 \\
\hline 1946 & 266073 & 2676 & 228 & 263169 \\
\hline 1947 & 178750 & - & - & 178750 \\
\hline 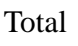 & 23344333 & 1372394 & 109546 & 21862393 \\
\hline
\end{tabular}


investigations of mining exploration in the MDOT have been carried out, but no records of industrial mining production have been published since the 1960s. Nonetheless, despite the demise of active mining, the villages of El Oro and Tlalpujahua have survived during recent decades, coexisting with the piles of tailings and archaeological industrial remains.

\subsection{Mineralogy and chemistry of the tailings today}

Most of the tailings have silt to clay textures (Siebe et al., 1996) with a grain size distribution of silt $(<80 \%)$ and significant variations of clay $(7-10 \%)$ and fine sand $(7-38 \%)$. $\mathrm{pH}$ varies from neutral to slightly alkaline (7.8-8.4) with variable conductivity (predominantly $>800 \mathrm{moh} \mathrm{cm}^{-1}$ ), which indicates a minor and variable concentration of metals. Mineralogically, the tailings consist of quartz $(>42 \%)$, clay $(9-19 \%)$, and calcite (11$12 \%)$. The amounts of opaque minerals vary little $(>2-$ $3 \%$ ) and consist of pyrite, argentite, galena, goethite, ilmenite, magnetite, hematite, arsenopyrite, chalcopyrite, and pyrrhotite (Maldonado Villanueva, 2008). The analyzed samples contained abundant silica (56-92 wt.\%), aluminum (5-13 wt. \%), iron (3-5 wt. \%), calcium (2.5-5 wt. \%), and potassium (1-2 wt. \%) (Corona Chávez et al., 2010). The samples have values that are potentially profitable, with $\mathrm{Au}$ $0.6-4.4 \mathrm{~g} \mathrm{t}^{-1}$ and $\mathrm{Ag} 1.8-178.3 \mathrm{~g} \mathrm{t}^{-1}$. The potentially toxic elements (PTEs) show values ranging from 3.0 to $83.9 \mathrm{ppm}$ for As, 7.4 to $808.6 \mathrm{ppm}$ for $\mathrm{Cu}, 16.5$ to $317.5 \mathrm{ppm}$ for $\mathrm{Pb}$, and 63.8 to $548.2 \mathrm{ppm}$ for $\mathrm{Zn}$. Some of these concentrations exceed the official safe levels established by the Mexican government. Finally, the nature of the tailings with respect to water chemistry anomalies (Nieto Monroy, 2007) is dominated by relatively neutral water, and therefore the PTE values of the tailings did not seem to generate acid drainage.

\section{The Los Cedros tailings dam}

On 14 December 1907, the mining company received the authorization to construct a tailings dam by a federal agency (Secretaría de Fomento). On 25 January 1908, the company submitted a project plan (involving 33 acres) to the federal agency and constructed within its property the base of the dam at the Sangria stream at an approximate elevation of $2850 \mathrm{~m}$ above sea level, besides the Los Cedros metallurgical plant and $\sim 500 \mathrm{~m}$ near the village of Tlalpujahua.

The impoundment began with the construction of a woodretaining wall, and during more than three decades this tailings dam, known as "Lamas Los Cedros" due to its proximity with Los Cedros metallurgical plant, was associated with the exploitation and generation of mine wastes from the Las Dos Estrellas mine (Fig. 3). These wastes eventually filled areas upstream of the gullies of Sangría and Dos Estrellas and drastically modified the morphology of the terrain around the
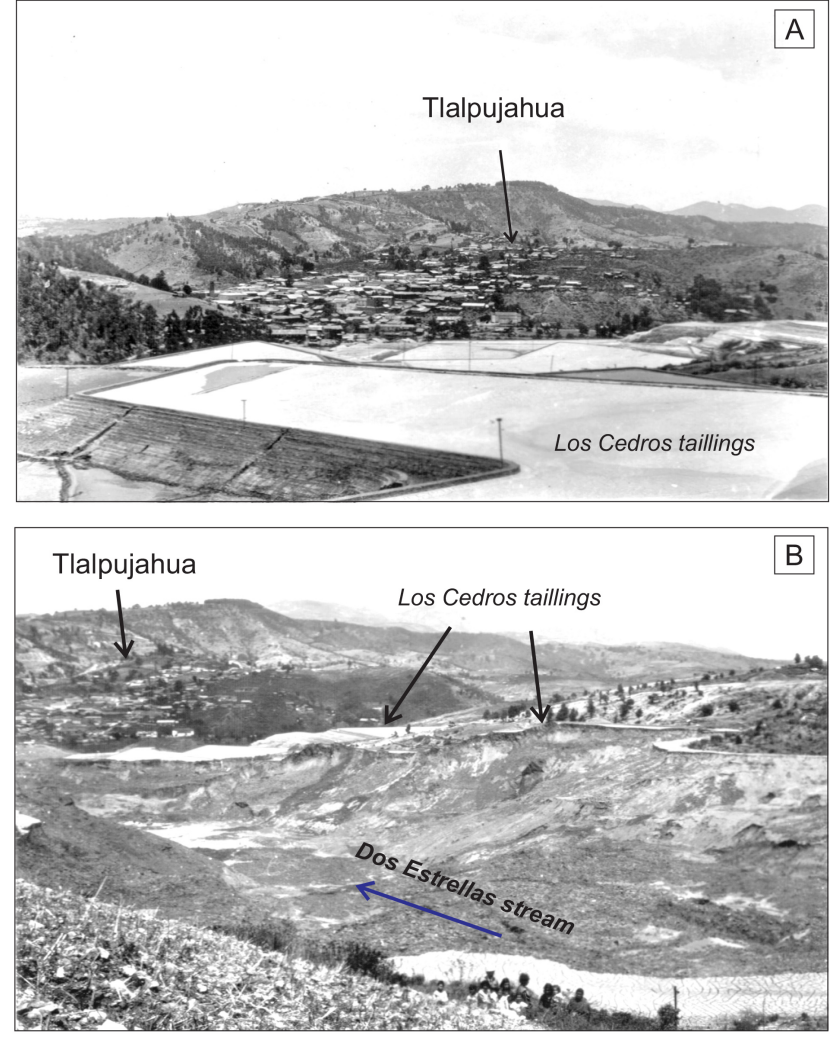

Figure 4. Panoramic views in 1937 from the southeast that show (a) Los Cedros tailings dam with a platform-like form prior to the collapse and (b) The tailings and the Dos Estrellas stream scoured by the flood after the collapse. See people standing on the hill in the foreground.

village of Tlalpujahua. Consisting of soft unconsolidated material associated with cyanidation processes, the mass of accumulated tailings was prone to remobilization.

The dam was built with wood to form a rectangular base where mine wastes were deposited after crushing, milling, cyanidation, and concentration processes were performed. The thickness of the tailings increased rapidly (ca. $35 \mathrm{~m}$ thick) to an approximate elevation up to $2875 \mathrm{~m}$ and acquired a platform-like form (Fig. 4a). From 1908 to 1936, the dam had an approximate volume of 14.7 million tons of mine waste (Uribe Salas, 2009; Corona Chávez et al., 2010; Table 1). In 1934, the mine had its largest production (820 603 tons, $\sim 2$ thousand $\mathrm{tday}^{-1}$ ). By 1935 , the mining company was projecting the construction of a new dam, suggesting that Los Cedros dam was already at or near its capacity. However, this new project of the company never materialized.

\subsection{Premonitory signs of a catastrophe}

Prior to the 27 May catastrophe, dam caretakers had reported cracks and softening of the impoundment surface, but apparently these reports were considered of no immediate danger (Bernal-Navarro, 2012). However, this author concluded that 


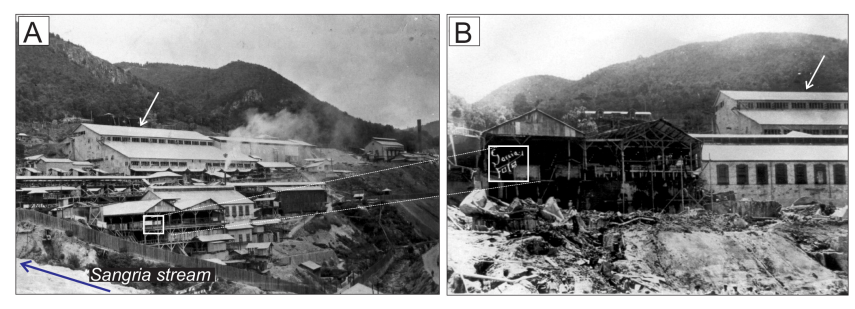

Figure 5. Aspects of Los Cedros Metallurgical plant of "Las Dos Estrellas" mining company at the Sangria stream, (a) before and (b) after the collapse. The white squares show the same location in both images, and an undisturbed roof of the Metallurgical plant (white arrows).

the base of the impoundment had softened due to the persistent rains and a permanent stream that existed at the base of the gully. In fact, on 26 May at 17:30 LT a $\sim 4$ t block detached from the lower part of the impoundment, leaving a $30 \mathrm{~m}$ wide hole. After this small landslide, mine dam caretakers warned villagers downstream to leave their homes because a large landslide may occur. Unfortunately, only a few paid any attention and this warning went unheeded. That same day, at around 23:20, another block detached from the impoundment, flooding the road to the Los Cedros metallurgical plant and the Juarez bridge. Intense rain accompanied by lightning persisted throughout the night.

\subsection{The 27 May 1937 flood known as "Las Lamas"}

At around 05:20 on 27 May, a large block (6-8 t) of tailings collapsed (Bernal-Navarro, 2012), producing a din followed after a few seconds by a powerful air blast - which we interpreted as an air pressure wave - that flattened trees, fences, and houses. Eyewitnesses described the flood as a muddy to sandy, fetid mass that rapidly channeled into, and filled, the stream. The ensuing flood rushed downstream, first hitting the Los Cedros metallurgical plant (Fig. 5a-b) and then the Trigueros hill (Fig. 4b). Inhabitants felt the ground shaking caused by the flood impact.

As the flood crashed against Trigueros hill, it diverted into an eastern upstream flood and a western downstream flood. The upstream flood flowed moved eastward a few hundred meters to the Los Cedros metallurgical plant, and then it waned and stopped. Instead the downstream flood rapidly transformed into a huge catastrophic wave at least $30 \mathrm{~m}$ in depth that swept towards the village of Tlalpujahua and San Jesus del Monte hill, which was crowned by a church. Between, Los Cedros metallurgical plant and San Jesus del Monte hill at least eight neighborhoods were completely destroyed (among which La Cuadrilla, Chinches Bravas, El Dos, and Las Cabecillas). Unfortunately, no detailed census of these neighborhoods existed; in fact, many people who were oblivious of the happenings at Tlalpujahua were working at the Dos Estrellas mine at the time.

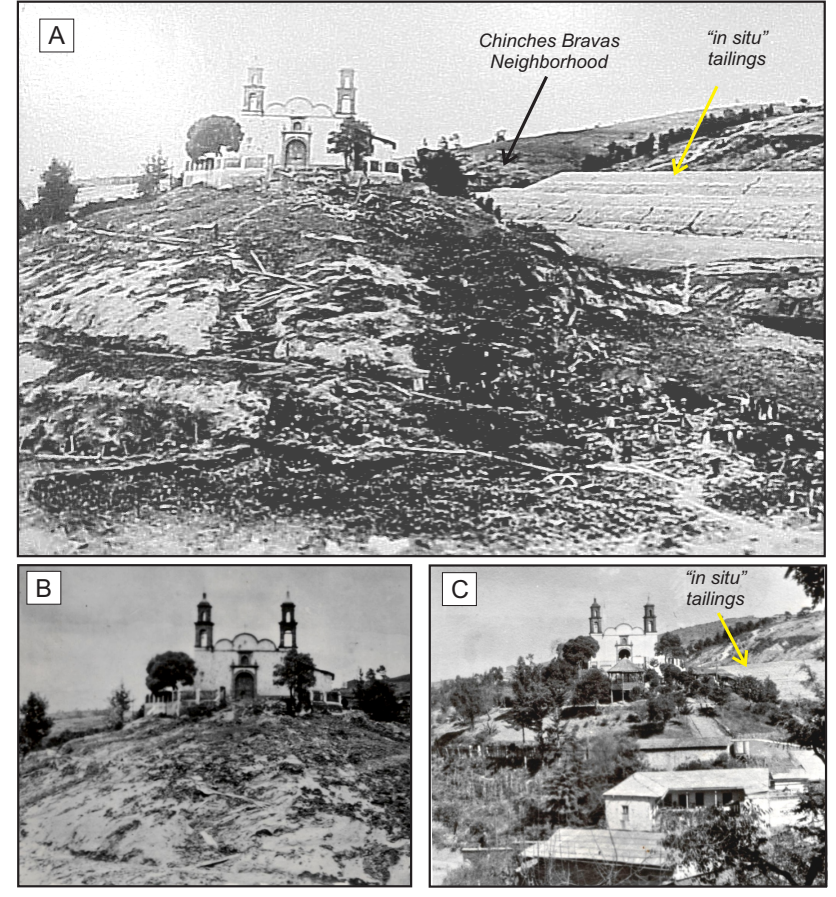

Figure 6. (a) Panoramic and (b) close-up view from the southwest of San Jesus del Monte hill and church after the 27 May 1937 flood with rubble, and wood planks dispersed on the surface and the striped slopes of the hill. (c) View of the same hill prior to the flood that shows houses on its southern slope.

Bernal-Navarro (2012) gathered eyewitness accounts of the catastrophic flood, which are summarized in the following for a better understanding of the nature of the event. The huge rushing flood uprooted everything along its path as houses, trees, electrical poles, people, and animals were swept away. The electrical poles and wires downed by the flood generated short circuits, producing explosions, lightning, and gases. The explosions burned trees everywhere, initiating short-lived fires. During all this chaos, the windy storm persisted. Some people climbed the hills of Trigueros and San Jesus del Monte to save themselves (Fig. 6a-c). Survivors who reached these, or lived at higher elevations, described that the flood had the appearance of a fetid lake moving downstream. The muddy flood scoured the outskirts of Tlalpujahua and moved around Jesus del Monte hill downstream along the Tlalpujahua River. Eyewitnesses observed roofs, logs, furniture, and plants floating in the flood.

After advancing $1 \mathrm{~km}$, the flood encountered El Carmen village, including the church, cemetery, and hamlets located along the eastern bank of the river. The flood partly destroyed the structures and buried the church with at least $2 \mathrm{~m}$ of mud. Some walls of the El Carmen church were destroyed, while others withstood the impact of the flood, including the painting of the "Madonna El Carmen" (Fig. 7a-b). Days after the catastrophic flood, inhabitants dug out the undamaged 

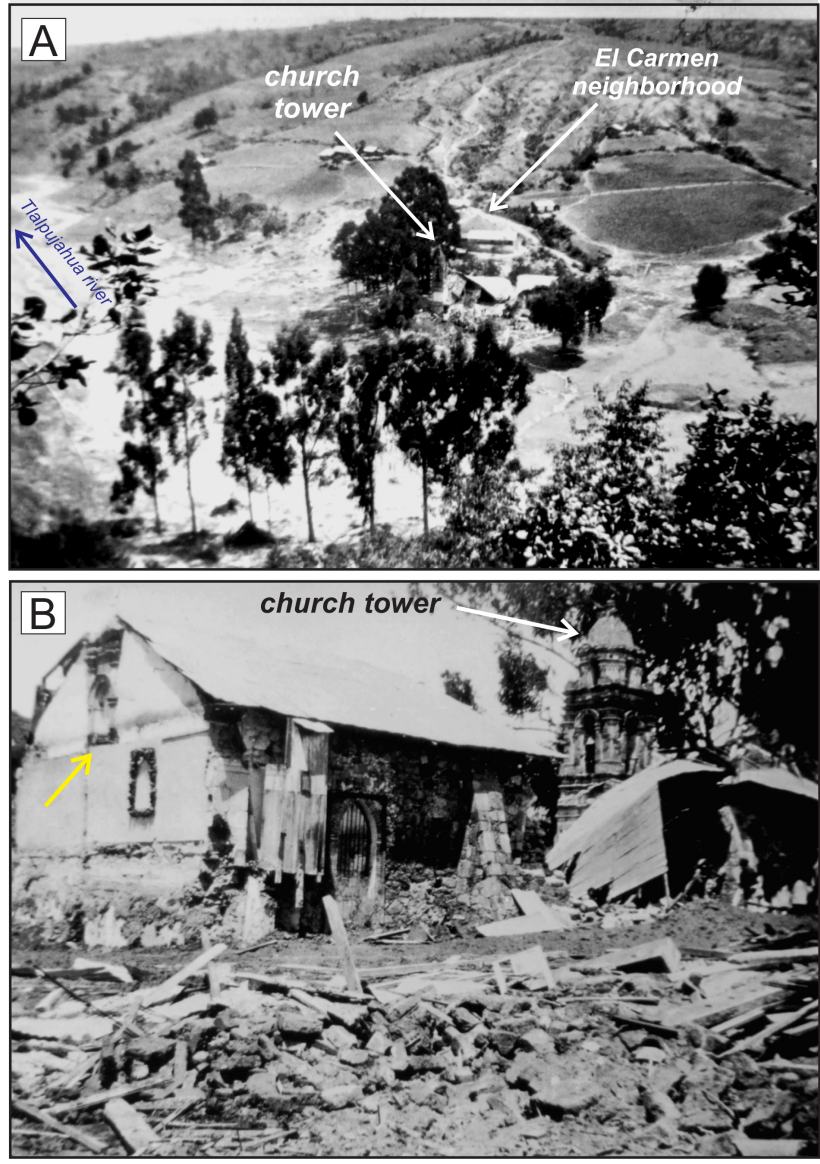

Figure 7. Photographs of El Carmen church after the 1937 flood and extent of the deposit along the Tlalpujahua River (white arrows) (a), and rubble and high-mud marks (yellow arrow) (b).

painting and paraded in a religious precession to transport it to the Tlalpujahua cathedral. Beyond El Carmen village, the muddy flood did not weaken but continued downstream for several more kilometers, but without encountering any other churches or hamlets. Because the muddy deposits had a whitish to light-gray color, the inhabitants nowadays know it as the "Las Lamas" flood deposit. The flood catastrophe produced a casualty toll of circa 300 people.

\section{Tailings flood deposit (TFD)}

The tailings flood deposit (TFD) is easily recognized along its extent because it is a light-gray to white color that contrasts with the local basement rocks (schists); red, yellow, and brown alluvial deposits; brown paleosols; and modern soil. The TFD appears as scattered outcrops along the Dos Estrellas and El Carmen (Tlalpujahua) streams.

\subsection{Distribution and volume}

Proximal exposures of the TFD (or Las Lamas) deposit occur around the San Jesus del Monte hill. At the top of this hill stands the San Jesus del Monte church (Figs. 6 and 8), which withstood the worst part of the 1937 flood. Today, this hill and church lie within the Tlalpujahua village limits. Proximal outcrops of Las Lamas flood are found on the San Jesus del Monte hill at minimum and maximum elevations of 2500 and $2540 \mathrm{~m}$, respectively. From this site on, the deposit can be traced downstream along the Tlalpujahua River (Fig. 7a). The deposit appears either as flat terraces (1$2 \mathrm{~m}$ thick) or as an overbank layer (20-40 cm thick) resting on top of older alluvial deposits and local basement rocks (andesites, schists, and paleosols). On the other hand, distal deposits occur as far as $9 \mathrm{~km}$ from San Jesus del Monte hill, at site 23 and at an elevation of $2350 \mathrm{~m}$ (Fig. 8), where it is $45 \mathrm{~cm}$ thick. Here, an eyewitness described that the flood traveled more than $1 \mathrm{~km}$ from this location, where it was still able to carry meter-size boulders. The most distal locations are further north at elevations of $2270 \mathrm{~m}$ along the Venta de Bravo Valley and close to the Federal Highway 15 where it connects to the cities of Maravatio and Atlacomulco. By considering a minimum extent of $11 \mathrm{~km}$ for the deposit and the present exposures, we estimate the deposit to cover a minimum area of about $982000 \mathrm{~m}^{2}$. If we assume an average thickness of $1 \mathrm{~m}$ for the deposit, we would obtain a minimum volume of $982000 \mathrm{~m}^{3}$ of material $\left(0.00098 \mathrm{~km}^{3}\right)$. We used a DEM for estimating the volume by using a common cut-and-fill command, obtaining a volume of $1492000 \mathrm{~m}^{3}$ $\left(0.00149 \mathrm{~km}^{3}\right)$. As described below, the flood moved with sediment-water concentrations of $\sim 50 \%$; therefore, if we assume such flow concentrations, then the flood might have had a minimum volume between 0.0019 and $0.0029 \mathrm{~km}^{3}$.

\subsection{Description and granulometry}

Twenty-three stratigraphic sections were measured along the path extension of the TFD (Fig. 8). From 10 of these sections, we sampled 14 specimens to perform granulometric analyses from -8 to $+12 \varphi$ grain sizes (Fig. 9). The correlation of these sections suggested that the deposit mainly consists of one massive layer. However, at some locations the deposit shows three (TL01) or two beds (TL08 and TL14) (Fig. 10ac). At locations between San Jesus del Monte (TL13) and El Carmen church (TL01) the deposit is soft and loose, but beyond $\mathrm{El} \mathrm{Carmen} \mathrm{church} \mathrm{it} \mathrm{is} \mathrm{partly} \mathrm{indurated} \mathrm{and} \mathrm{contains}$ void spaces in all sections.

The TFD shows a light-gray to whitish color and has a flat planar lower contact and an upper contact grading into the modern soil. It usually overlies a brown to orange paleosol that may contain pottery or other artifacts (site TL13) or it stands over the local green-schist basement (site TL18) (Fig. 10c). At section TL14, the TFD deposit overlies the 1937 soil, a brown hyperconcentrated flow, a brown paleosol, 


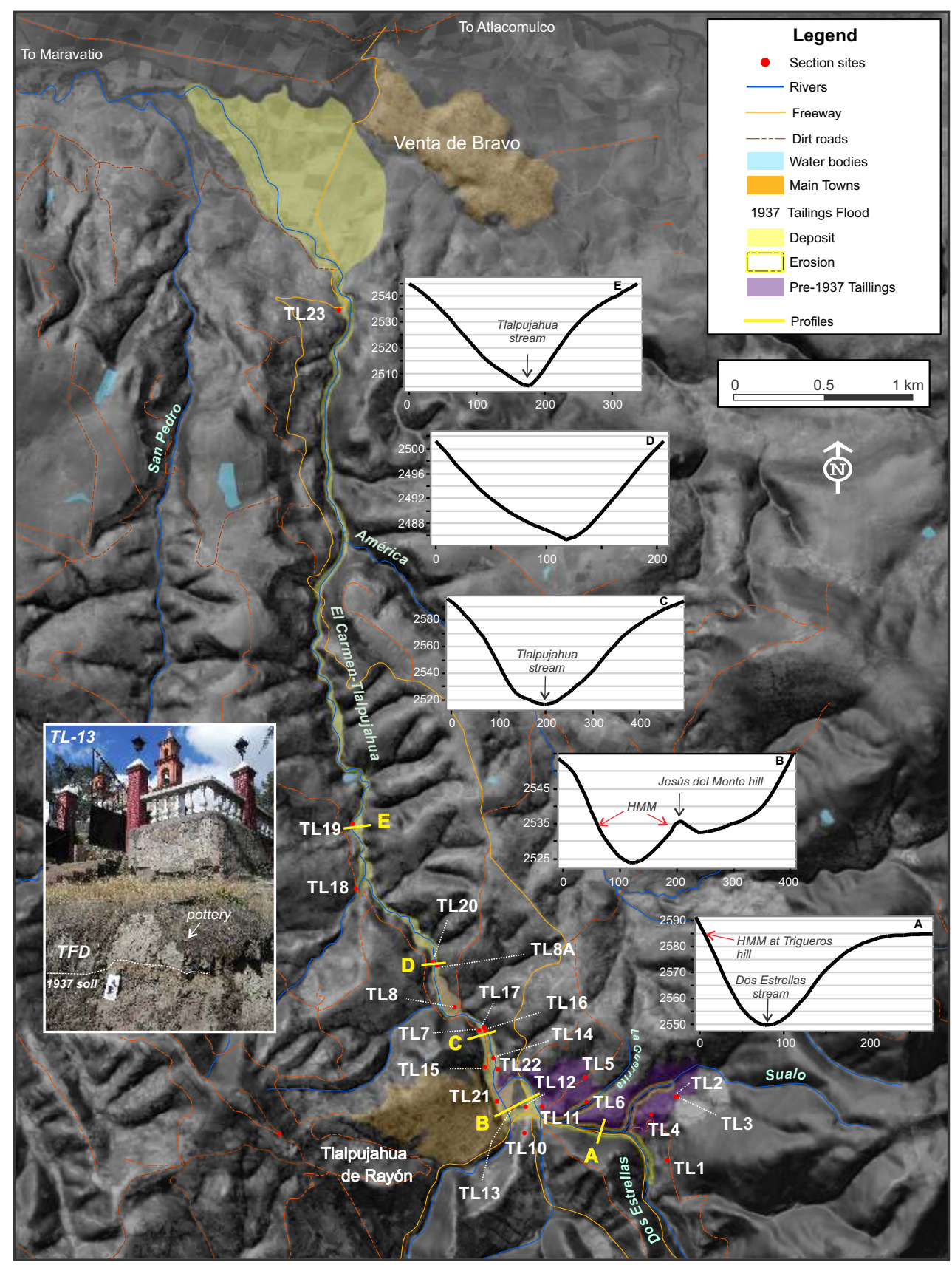

Figure 8. Shaded relief map of the MDOT displaying the location of Tlalpujahua and Venta de Bravo villages, the extension of Los Cedros tailings in 1937, and the present extension of the 1937 flood deposit. Red circles are stratigraphic sections measured during this study. Insets are cross profiles indicating the shape of the flow channel and some flow indicators as high-mud marks.

a debris flow deposit with rounded to angular block pieces of broken glass in a coarse-sand matrix, and the underlying schists (Fig. 10a). All this sequence stands beside or atop the remains of an old bridge wall. This stratigraphic column suggests that other historical fluvial debris flows have occurred at Tlalpujahua.

Along its extent, the TFD has variable thicknesses, for instance around $40 \mathrm{~cm}$ at section TL-13 (San Jesus del Monte church), $2.8 \mathrm{~m}$ at site TL16 (0.8 $\mathrm{km}$ downstream), and $40 \mathrm{~cm}$ at the farthest location (TL-23) (Fig. 8). As a whole, the deposit is massive, matrix-supported ( $>56 \%$ ), and composed of sandy to clayey particles (Fig. 9, Table 3). These characteristics indicate that the deposit had an unimodal granulometric distribution with the main mode shifting from 1 to $4 \varphi$ (Table 3) and good sorting $(0.55-1.35 \sigma \varphi)$. The structure, texture, and grain size characteristics of TFD suggest it corre- 
Table 2. List of stratigraphic sections along the Las Lamas food deposit.

\begin{tabular}{|c|c|c|c|c|}
\hline \multirow[t]{2}{*}{ Section number } & \multicolumn{2}{|c|}{ UTM coordinates } & \multirow{2}{*}{$\begin{array}{r}\text { Elevation } \\
(\mathrm{m})\end{array}$} & \multirow[t]{2}{*}{ Brief description } \\
\hline & $\mathrm{X}$ & $\mathrm{Y}$ & & \\
\hline TL01 & 378493 & 2190102 & 2619 & Molinos \\
\hline TL02 & 378552 & 2190530 & 2620 & Sualo tailings \\
\hline TL03 & 378562 & 2190526 & 2621 & Upper part of the tailings \\
\hline TL04 & 378387 & 2190406 & 2548 & Jale CB \\
\hline TL05 & 377939 & 2190661 & 2586 & Deposits at the approximated location of La Guerrita village \\
\hline TL06 & 377951 & 2190492 & 2562 & Flood deposits at La Guerrita stream \\
\hline TL07 & 377227 & 2190976 & 2520 & In situ tailings at a flat terrace \\
\hline TL08 & 377063 & 2191131 & 2511 & El Carmen village \\
\hline TL09 & 375886 & 2190278 & 2581 & The El Gallo viewpoint \\
\hline TL10 & 377534 & 2190283 & 2415 & Undisturbed site of today's restaurant Los Arcos \\
\hline TL11 & 377655 & 2190462 & 2393 & In situ tailing deposits at the Nieto's stone quarry in Tlalpujahua \\
\hline TL12 & 377450 & 2190454 & 2385 & Quarry west of San Jesus del Monte with flood deposit atop schists hill \\
\hline TL13 & 377542 & 2190459 & 2408 & $\begin{array}{l}\text { Base of the San Jesus del Monte stairway flood deposit over paleosol } \\
\text { with abundant pottery }\end{array}$ \\
\hline TL14 & 377328 & 2190789 & 2393 & $\begin{array}{l}\text { Along the Tlalpujahua stream at the old stone bridge, flood deposit on } \\
\text { top of older debris flow deposits }\end{array}$ \\
\hline TL15 & 377269 & 2190725 & 2415 & Along the Tlalpujahua stream on top of the flood deposit's terrace \\
\hline TL16 & 377272 & 2190969 & 2394 & Along the Tlalpujahua stream on top of the flood deposit's terrace \\
\hline TL17 & 377258 & 2190993 & 2400 & $\begin{array}{l}\text { Along the Tlalpujahua stream, the flood deposits overlie a paleosol and } \\
\text { older flood deposits }\end{array}$ \\
\hline TL18 & 376400 & 2191927 & 2387 & $\begin{array}{l}\text { Road El Carmen-Rayón beyond the bridge; the flood deposits overlie a } \\
\text { paleosol and schists }\end{array}$ \\
\hline TL19 & 376378 & 2192364 & 2373 & In the Tlalpujahua stream a flood terrace in a corn field \\
\hline TL20 & 376922 & 2191436 & 2394 & In the Tlalpujahua stream a flood terrace in a corn field \\
\hline TL21 & 377348 & 2190496 & 2413 & $\begin{array}{l}\text { A few hundred meters ahead of the entrance of the Tlalpujahua-El } \\
\text { Carmen road, west side }\end{array}$ \\
\hline TL22 & 377354 & 2190712 & 2415 & At La Esperanza cabins northeast from San Jesus del Monte \\
\hline TL23 & 376284 & 2195817 & 2207 & Paved road Tlalpujahua-Rayón indurated flood deposit \\
\hline
\end{tabular}

sponds to a hyperconcentrated flow deposit (Fig. 9). In some sections, however, the deposit may contain scattered gravel to boulder-size fragments, as in section TL-01B (up to $40 \%$ ) or at section TL-21 (43\%) (Table 3). In these sections, the granulometric distribution of TFD is bimodal, with a coarse mode $(-5$ to $-3 \varphi)$ not shown at other locations, a fine mode $(1.8-4 \varphi)$, and medium sorting (5.2 to $1.1 \sigma \varphi)$. The structure, texture, and grain size characteristics of the deposit at these specific locations allow us to classify them as debris flow deposits.

At site TL13, along the steps of the San Jesus del Monte church, the TFD varies in thickness from 80 to $40 \mathrm{~cm}$. It overlies an anthropogenic layer rich in pottery shards, charcoal and other remains, and older debris flow and the basement green schists (Fig. 11).

Site TL01 (remains of the El Carmen church) exhibits an extraordinary sequence of the TFD made of three different layers $(\mathrm{A}-\mathrm{C})$ separated by erosive contacts. The intermediate unit, which is rich in boulder-size fragments and church blocks, seems to correlate with the deposit at all other locations (Fig. 12a-b). These layers are light tan in color, massive, and partly indurated with voids. The lowermost layer
A rests on the 1937 El Carmen church floor (Fig. 12b). It is $40 \mathrm{~cm}$ thick and contains sporadic subangular clasts usually smaller than $3 \mathrm{~cm}$ set in a silty to clayey matrix $(\sim 95 \%)$.

Layer B ( $\leq 0.85 \mathrm{~cm}$ thick) consists of angular to subangular clasts (30-84 cm in diameter) set in a clayey-silty matrix $(80 \%)$. This layer contains stone church blocks, glassware, pottery, bricks, wood chips, and charcoal. Layer C $(\leq 60 \mathrm{~cm}$ thick) is heterolithologic with ignimbrite and metamorphic subangular fragments ranging in size from 1.5 to $6 \mathrm{~cm}$ in diameter. The clasts are dispersed in the middle part of the bed within a sandy to silty matrix (70-75\% wt.). The upper portion of layer $\mathrm{C}$ grades into the modern soil.

\section{Discussion}

Mining activity in the MDOT reached its apex during the first half of the XX century, when the Las Dos Estrellas company was established. At that time, $\geq 2$ million tons of rock were extracted daily producing alike amounts of waste materials disposed into the tailings. As mentioned previously, the construction of the Los Cedros tailings dam in 1908, and accu- 
Table 3. Granulometric analyses and statistical parameters of samples collected along the tailings flood deposit.

\begin{tabular}{|c|c|c|c|c|c|c|c|c|c|c|}
\hline Sample & Gravel & Sand & Silt & Clay & Fines & Matrix & $\operatorname{Md} \Phi$ & $\sigma \varphi$ & Sk & $\mathrm{Cu}$ \\
\hline & $(-8 \Phi \mathrm{a}-2 \Phi)$ & $(-1 \Phi$ a $4 \Phi)$ & $(5 \Phi$ a $8 \Phi)$ & $(\geq 9 \Phi)$ & (Silt + clay $)$ & $(-1 \Phi$ a $9 \Phi)$ & & & & \\
\hline TL-01A & 4.2 & 64.41 & 27.93 & 3.46 & 31.39 & 95.80 & 6.2 & 2.73 & -0.21 & 0.97 \\
\hline TLA-01B & 39.67 & 56.54 & 2.26 & 1.53 & 3.79 & 60.33 & -1.1 & 2.8 & -0.32 & 0.83 \\
\hline TL-01C & 7.06 & 66.14 & 23.71 & 3.09 & 26.80 & 92.94 & 2.12 & 4.15 & -0.38 & 1.53 \\
\hline TL-13D1 & 3.39 & 94.22 & 2 & 0.39 & 2.39 & 96.61 & 2.3 & 0.93 & -0.19 & 1.34 \\
\hline TL-13D2 & 0 & 98.96 & 0.84 & 0.20 & 1.04 & 100 & 2.6 & 0.55 & 0.09 & 1.01 \\
\hline TL-14D & 0 & 96.35 & 2.98 & 0.67 & 3.65 & 100 & 4.3 & 0.57 & -0.04 & 0.95 \\
\hline TL-14C & 0 & 97.41 & 2.08 & 0.51 & 2.59 & 100 & 2.55 & 0.7 & 0.07 & 0.99 \\
\hline TL-15B & 0 & 97.7 & 2.01 & 0.29 & 2.30 & 100 & 1.75 & 1.35 & 0.26 & 0.8 \\
\hline TL-18 & 0 & 89.04 & 9.26 & 1.70 & 10.96 & 100 & 1.8 & 0.98 & 0.38 & 0.9 \\
\hline TL-19 & 0 & 89.3 & 8.98 & 1.72 & 10.70 & 100 & 2.6 & 0.75 & 0.11 & 1.67 \\
\hline TL-20 & 0 & 93.3 & 5.87 & 0.83 & 6.70 & 100 & 3.15 & 1.15 & -0.48 & 0.71 \\
\hline TL-21 & 8.27 & 80.67 & 5.9 & 5.16 & 11.06 & 91.73 & -6.25 & 5.23 & 0.73 & 0.51 \\
\hline TL-22 & 1.97 & 88.9 & 6.67 & 2.46 & 9.13 & 98.03 & 2.6 & 1.05 & -0.19 & 2.41 \\
\hline TL-23 & 11.16 & 88.74 & 0.05 & 0.05 & 0.10 & 88.84 & 0.95 & 1.73 & -0.3 & 1.24 \\
\hline
\end{tabular}

Sk: skewness; $\mathrm{Cu}$ : curtosis.

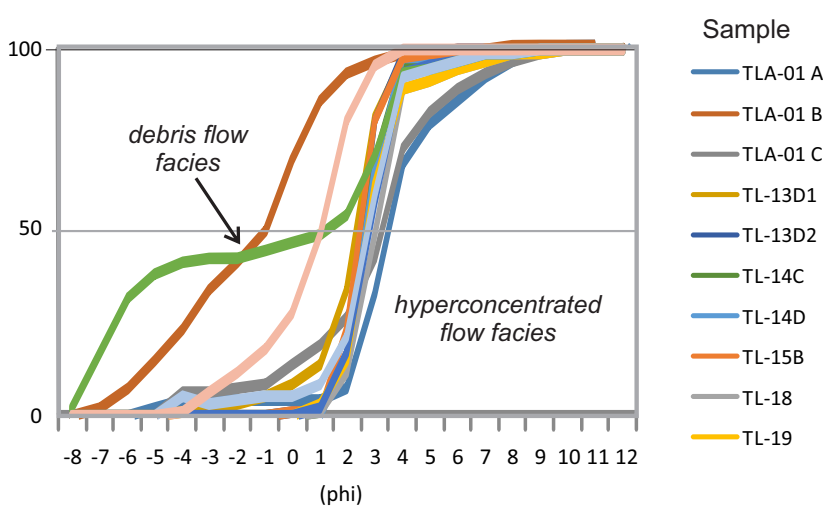

Figure 9. Cumulative curves of the TFD deposit at different distances from the source. Most of the deposits are fine-grained (hyperconcentrated flow deposits), while a few exposures contained boulder- and gravel-sized particles set in a silty matrix (debris flow deposits). See Fig. 8 for locations of samples.

mulation of waste materials within it, drastically modified the geomorphology and the drainage system around the village of Tlalpujahua. The mass of $>2$ million tons of soft unconsolidated material associated with cyanidation processes was prone to remobilization. Such morphological and hydrological modifications of the landforms were primed for some triggering phenomenon to release a large amount of material in a catastrophic way.

Taking into account all the previous information of the event, the worldwide literature of similar events (Rico et al., 2008a, b), we conclude that several factors combined to produce the terrible flood catastrophe. First of all, the impoundment was built upstream, infilling the Dos Estrellas valley and changing the morphology and drainage pattern

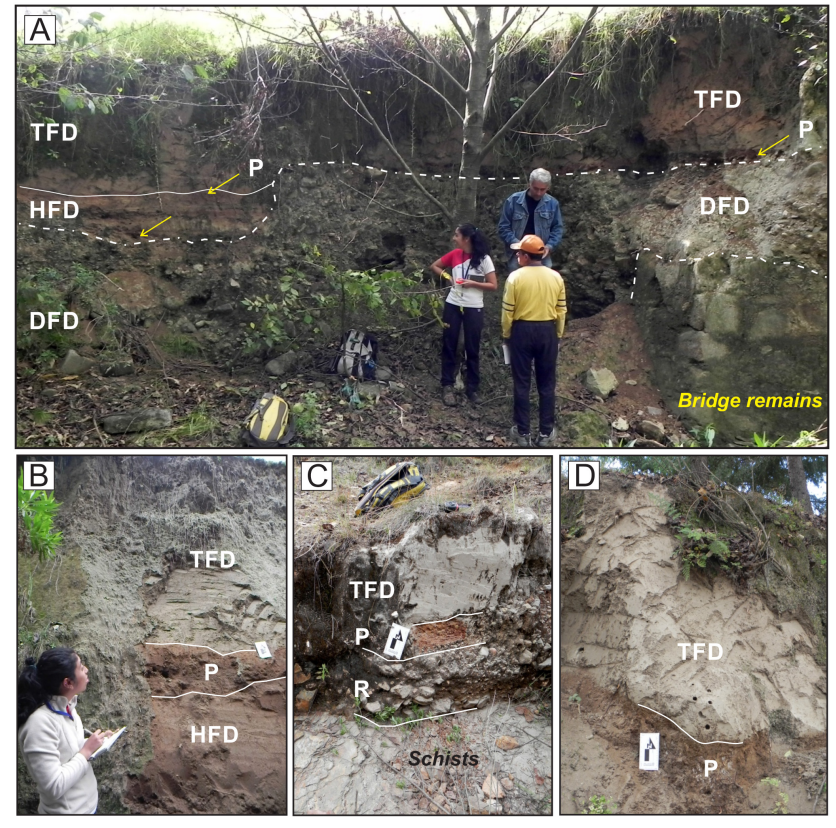

Figure 10. Aspects of the tailings flood deposit (TFD) at three sections along its path. (a) At section TL-14, the TDF rests over a paleosol, a thin hyperconcentrated flood deposit (HFD), another paleosol, and a basal debris flood deposit (DFD) that contains pieces of bottle glass. The TFD forms a paleo-channel that stands against the remains of an old stone bridge. (b) View of the TFD at section 17 overlying a paleosol and a lower brown hyperconcentrated flood deposit (HFD) rich in sand-size particles. (c) At section TL-18 the TFD overlies a poorly developed paleosol, a reworked bed with gravel-sized fragments and schists from the local basement. (d) At section TL-19 the deposits rest directly on top of a thicker paleosol. 

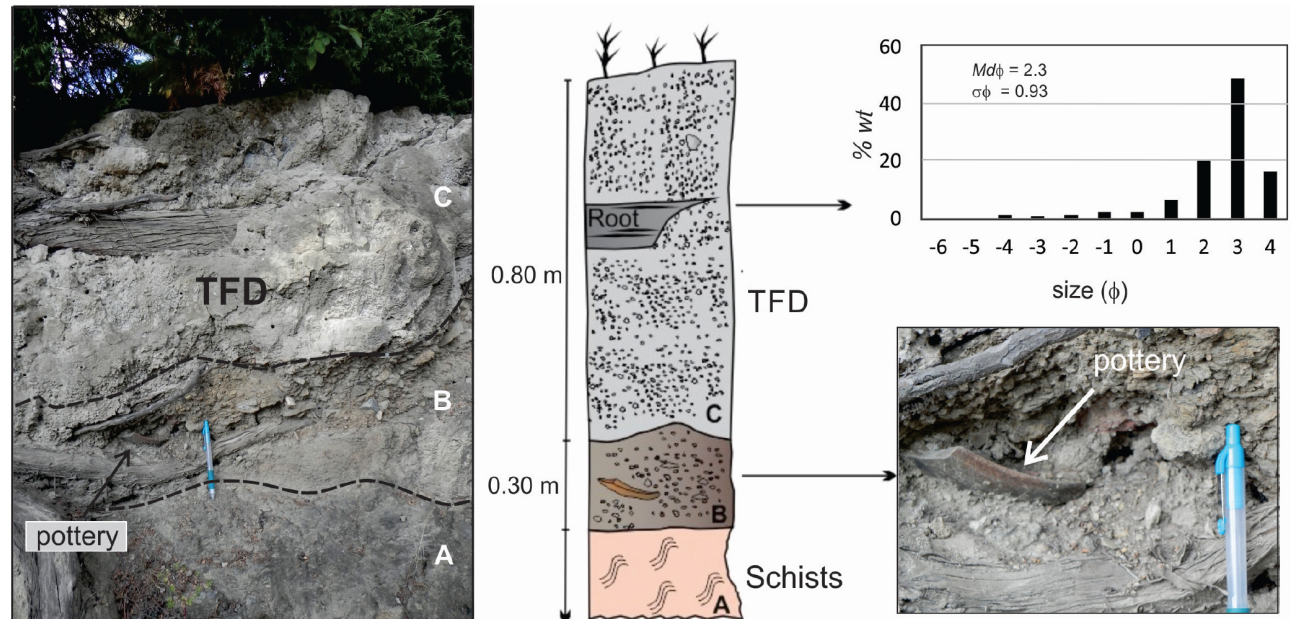

Figure 11. Section TL13 looking to the west at the steps of San Jesus del Monte hill. The section shows from the base schists a debris flow deposit that turns into a pottery-rich soil and the whitish TFD atop grading into the modern soil cover with trees.

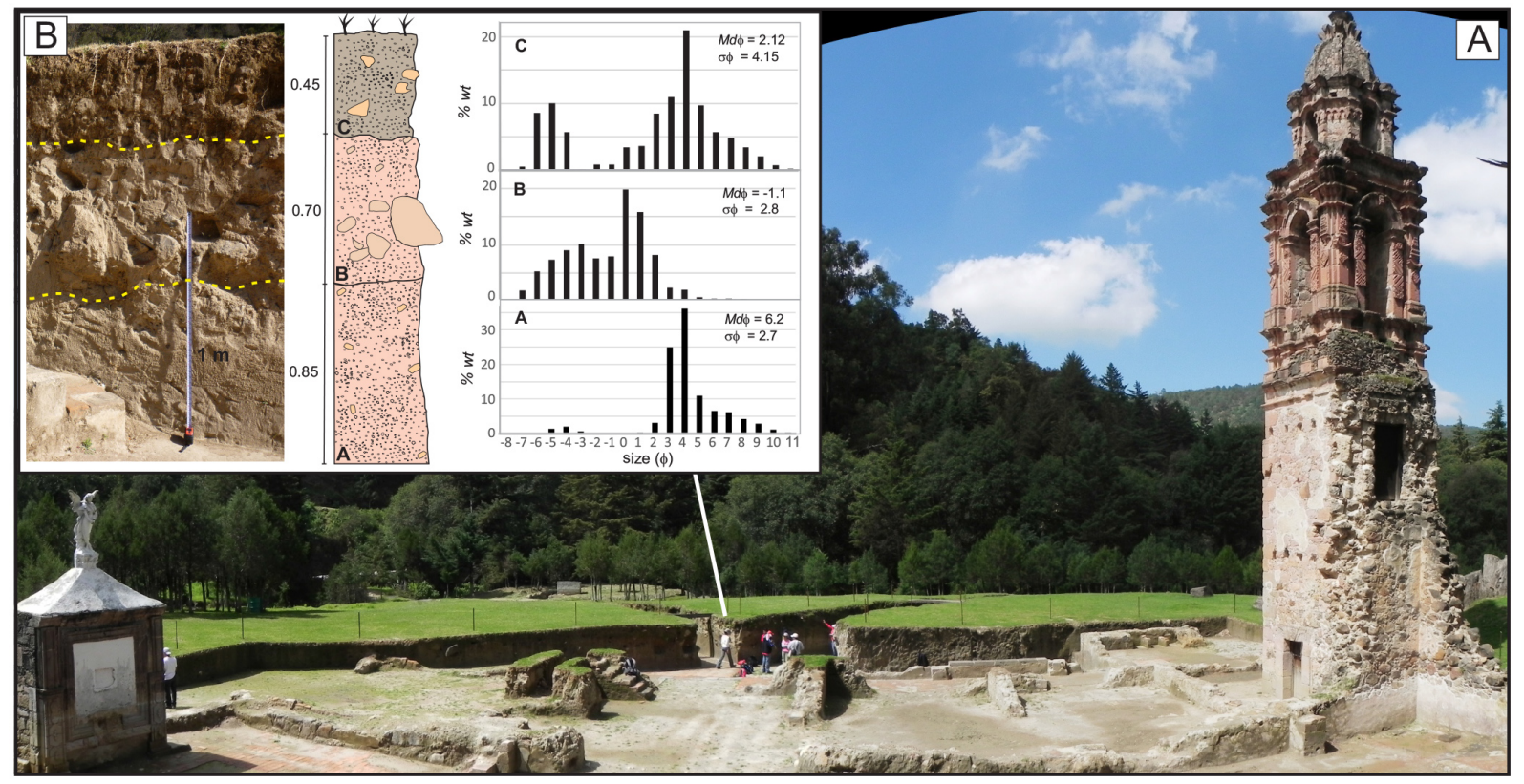

Figure 12. (a) Panoramic view from the east of the remains of El Carmen church buried by the tailings flood deposit (section TL-01). The excavation of the church remains exposed the ancient floor of the sanctuary. (b) Stratigraphic column showing three beds separated by dashed yellow lines and their granulometric bimodal distributions.

of the perennial and seasonal streams. Secondly, prior to the breaching of the dam, some people witnessed diverse small landslides caused by softening of the impoundment. This was likely facilitated by seepage of a small stream that flowed at the bottom of the tailings dam (Bernal-Navarro, 2012). At that time, the people living downstream were alerted, but the authorities did not evacuate them or take any additional preventive measures. Therefore, a combination of bad management operations and the lack of preventive measures to evacuate people at risk played an important role in the catastro- phe, as has been emphasized by Gipson (2003) at other sites around the world. These anthropogenic factors compounded the effect of sustained torrential rainfall in the region that saturated and softened the tailings dam material, culminating in the breaching of the impoundment that suddenly released a silty, fetid mass that rapidly transformed into a catastrophic flood. To date, no Mexican regulations exist to prevent the environmental impact of tailings ponds, as has been proposed in other countries beginning several decades ago. Yet, despite recent advances, environmental problems and 


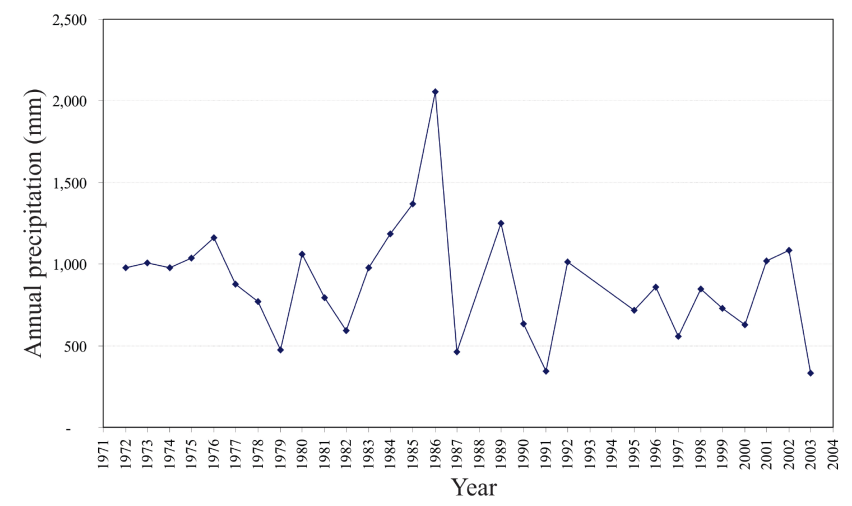

Figure 13. Timeline showing the year 1986 with estreme precipitation recorded in the region of MDOT. Data from the 15183-El Oro meteorological station from Corona Chávez et al. (2010).

dam failures have continued to occur (East, 2000), even during the past decade (Azam and Li, 2010). For example, the 4 October 2010 dam failure in Hungary released $700000 \mathrm{~m}^{3}$ of tailings with fatal consequences, underscoring the critical importance to understand, and possibly to mitigate, these failures. A step forward regarding the study and analyses of dam failures was proposed by Neves Correia dos Santos et al. (2011), who applied a failure modes and effects analysis (FMEA) at Cerro do Lobo tailings, Portugal.

\subsection{Failure of the Tlalpujahua tailings dam}

Unfortunately, no local weather stations existed around the MDOT before the failure. The first station (15183-El Oro), which became operational in 1972, is relatively close to the Los Cedros metallurgical plant (Fig. 5). This station has a continuous rainfall record from 1972 to 2002, with some small gaps in 1988, 1993, and 1994. By using descriptive statistical methods, Martínez Medina et al. (2012) concluded that the MDOT showed an average precipitation of $900 \mathrm{~mm}$ per year. These results resemble the regional rainfall weather (see Fig. 2). However, it is worth noting that, during this period, at least 2 years had atypical rainfall (exceeding $>1200 \mathrm{~mm}$ ); one of them occurred in 1986, when the rainfall exceeded $2000 \mathrm{~mm}$ (Fig. 13). With this study, Martínez Medina et al. (2012) concluded that return periods for $1800-2100 \mathrm{~mm}$ rainfalls occurred every 29 years. On the other hand, there is evidence that atypical rainfall periods have caused other catastrophic debris flows along the Tlalpujahua-Americas stream, as has been attested by at least two historical floods (older than 1937) observed in the stratigraphic record (site TL-14). One of them had a coarser granulometry than the 1937 flood and contained broken glass and blocks from an old bridge destroyed by this debris flow, suggesting that previous events along the Tlalpujahua-Americas stream have had larger magnitudes. By considering the time recurrence of the most recent extreme rainfall event (in 1986) and the sedimentological record, we may expect that an atyp- ical event may occur in the near future in Tlalpujahua, and consequently the risk is still present.

\subsection{Reconstruction of events}

Eyewitness accounts clearly described the passage of at least two floods on the morning of 27 May 1937. At 05:40. (Bernal Navarro, 2012) the first landslide from tailings dam caused a huge roar that was suddenly accompanied by an air pressure wave. The roaring noise likely alerted people in Tlalpujahua and spurred them to try to escape. People in their pajamas or partly nude were seen walking, crawling, and running uphill, by natural instinct, to Trigueros, Tlalpujahua, and to Jesus del Monte church. It is not clear how many people were able to flee this first flood wave, which was as deep as $20 \mathrm{~m}$ around Tlalpujahua. People who managed to save themselves observed the horror of terrified, screaming people being engulfed by the flood and disappearing downstream. Some survivors were able to rescue other people, although they failed in their attempts to either save lives or rescue their belongings, when they were cut off by the flood. From such accounts, it is clear that the main devastating flood was followed by several smaller waves and surges. The stratigraphic reconstruction of the deposit shows at least three hyperconcentrated or debris flow deposits associated with the same number of floods. The best exposure of this interpretation is seen at El Carmen church (TL01). This conclusion was confirmed by the detailed governmental report carried out by an expert who described three flow surges and several other details and facts of the tragedy (Antonio López Portillo, 1937 in Juárez Bobadilla, 2007).

\subsection{Flood behavior}

As previously discussed, there were at least three flow surges. The first and largest flow originated in the Sangria gully, and the later smaller flows involved sources at the Dos Estrellas stream. Eyewitness accounts, historical photographs, and recent fieldwork helped us to understand the dynamic behavior of the largest flow. The flow was sourced from someplace along the Sangria gully, the initial mass fed by the finegrained tailings (silt and sand material) and cyanide mixed with water that rapidly rushed down the gully. At ca. $0.7 \mathrm{~km}$ from the probable source, the flow initially struck the Los Cedros metallurgical plant and impacted against Trigueros' northern side hill, scraping ca. $30 \mathrm{~m}$ of forest (Fig. 14a).

Velocities of the flow were estimated from runup obstacles aligned perpendicular to the flow by using the simple relationship $v=\sqrt{ } 2 g h$, in which $h$ is the runup height and $g$ is the acceleration due to gravity (Sheridan et al., 2005). High mud marks observed in photographs were about $30 \mathrm{~m}$ high, suggesting flow speeds of $25 \mathrm{~m} \mathrm{~s}^{-1}$. As emphasized by Sheridan et al. (2005) these estimates are considered minimum velocities because this equation does not account for friction. 

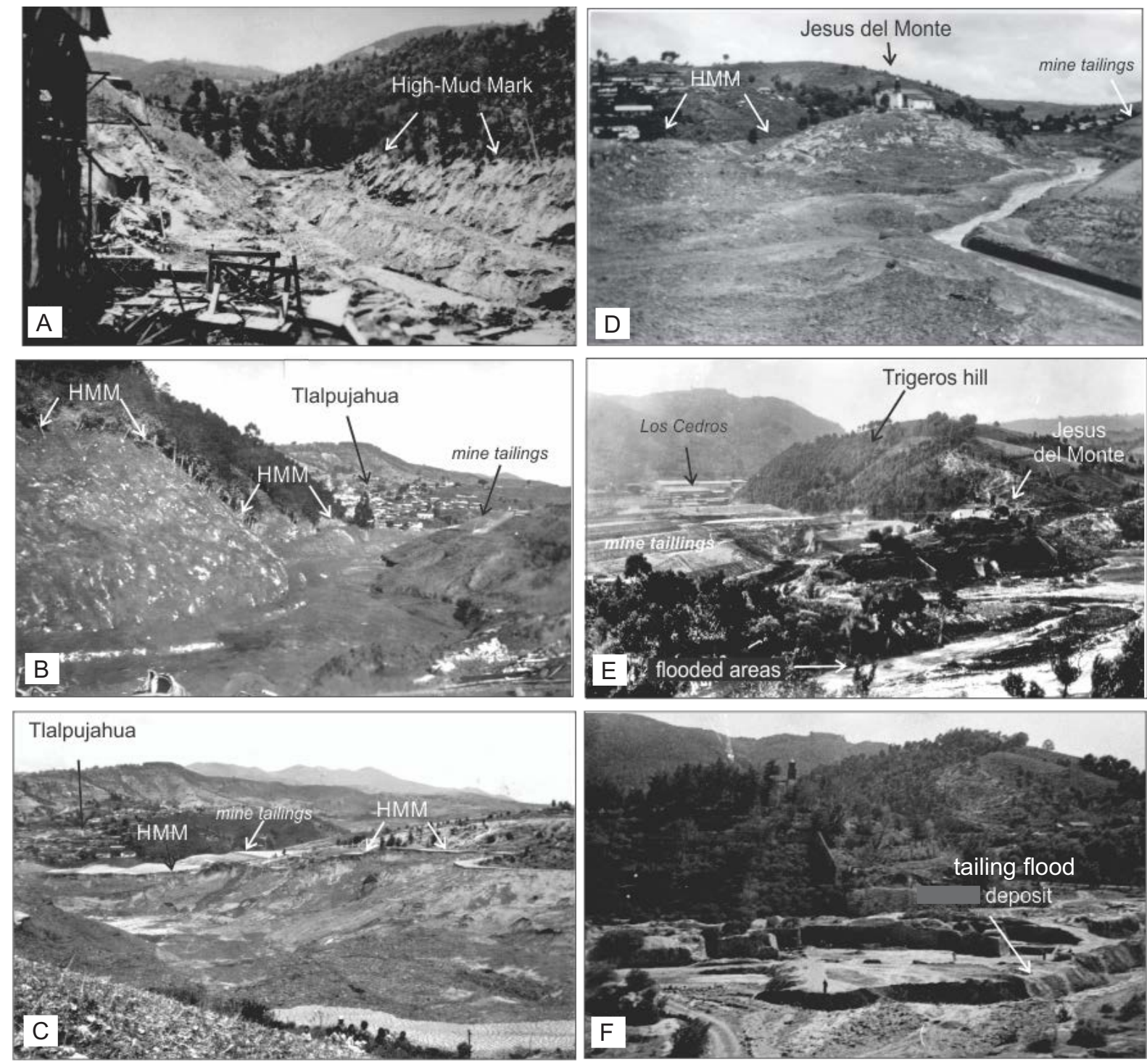

Figure 14. Photographs of damage caused by the tailings flood in 1937 at different locations of this study: Los Cedros metallurgical plant (a), Trigueros hill (b), the Dos Estrellas stream between Trigueros and Jesus del Monte (c), and Jesus del Monte (d)-(f). HMM: high-mud marks.

To determine the section area and the discharge of the flood along its path, we used the OriginLab program to create cross sections of the channel, and we defined the polynomially best-matched topographic profile of the channel ( 0.97 ratio) with order three to nine polynomials. Once the area of the section was obtained, Eq. (1) was used to determine the discharge

$$
\int_{a}^{b} y \mathrm{~d} x=Q / v \ldots . .1
$$

where $\int_{a}^{b} y \mathrm{~d} x$ is the function that satisfied the shape of the channel bottom (polynomial), $Q$ is discharge, and $v$ is veloc- ity obtained from Eq. (2):

$$
Q=\int_{a}^{b} y \mathrm{~d} x(\sqrt[2]{2 g h}) \ldots 2,
$$

assuming that $\sqrt[2]{2 g h}$ is the estimated flow velocity without considering basal friction (Sheridan et al., 2005).

At the breached dam we considered a thickness of $25 \mathrm{~m}$ and a width of $120 \mathrm{~m}$. The calculated area with the OriginLab program was $1765.7 \mathrm{~m}^{2}$, for which we obtained a flow discharge of $Q=39085 \mathrm{~m}^{3} \mathrm{~s}^{-1}$ with flow velocities of $24 \mathrm{~m} \mathrm{~s}^{-1}$. The impact of the flood against Trigueros hill caused it to split into a short-lived, less powerful upstream surge that only advanced a few hundred meters and the huge 

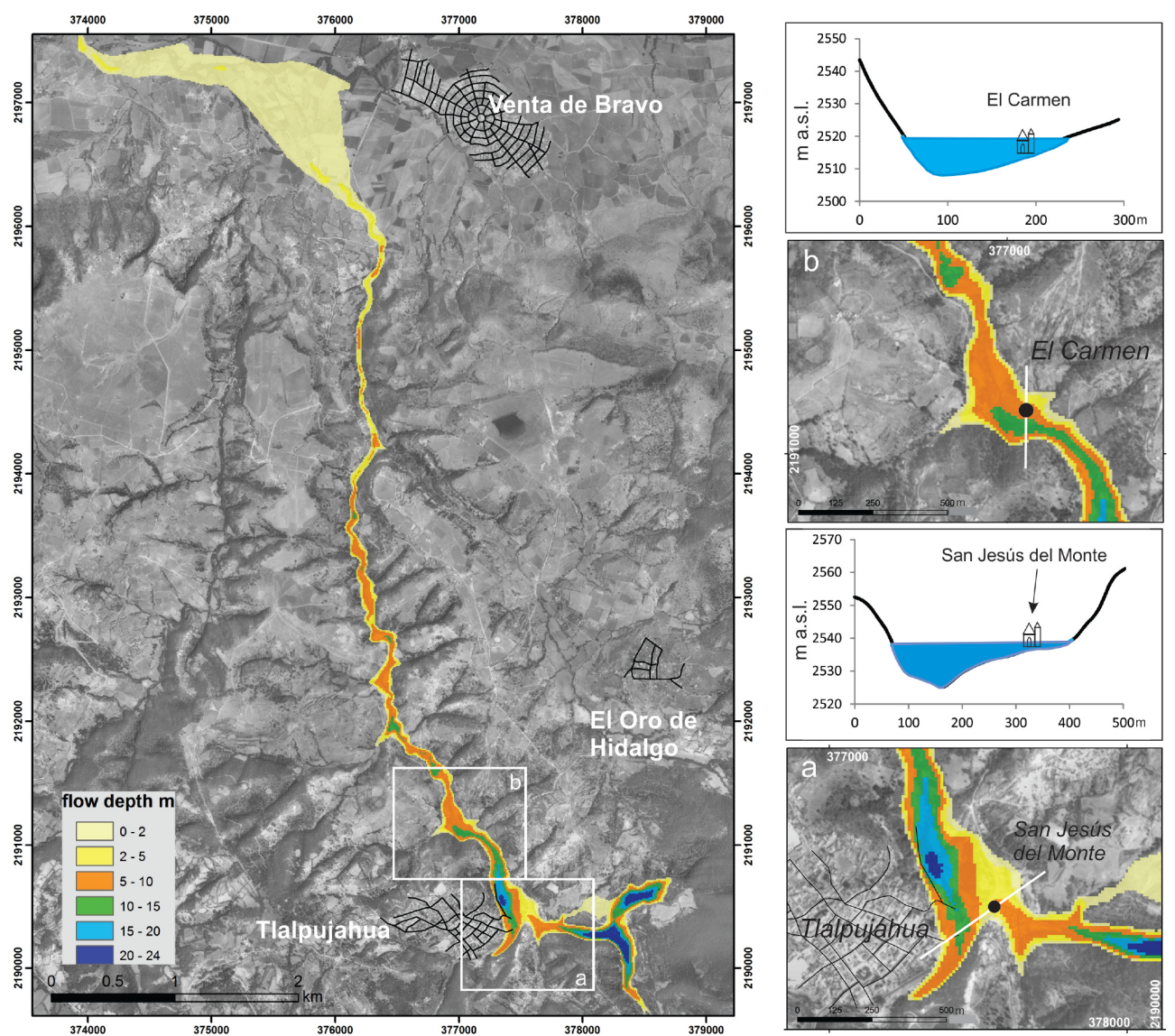

Figure 15. Map showing the maximum depth of the simulated flow and topographic profile at (a) Jesus del Monte and (b) El Carmen churches to illustrate the maximum inundation limits.

sustained flow wave that rushed downstream towards the village of Tlalpujahua, scouring the old road, trees, and tailings from the retaining wall of the dam (Fig. 14b). Unfortunately, several neighborhoods stood downstream and were completely devastated by the flood (Fig. 14c). Pictures of the places and remains of these neighborhoods show the maximum thickness of deposits and the high-water marks suggesting that the wave was moving as an hyperconcentrated flow (ca. $50 \%$ sediment concentration). Downstream, the Tlalpujahua River carved a gully between the outskirts of the Tlalpujahua village and the Jesus del Monte hill, which was surrounded by several neighborhoods, including La Cuadrilla, at its base.

The catastrophic flood reached depths of approximately $20 \mathrm{~m}$ in this area, destroying everything in its path, knocking down all standing things, and scouring the ground to the base of the Jesus del Monte church located ca. $1.4 \mathrm{~km}$ from the flood source (Fig. 14d-f). Eyewitnesses reported that the moving flood was striking the frontal walls of the church to the point of tilting them. The flood reached a maximum elevation of $20 \mathrm{~m}$ at the church for estimated speeds of $20 \mathrm{~m} \mathrm{~s}^{1-}\left(60 \mathrm{~km} \mathrm{~h}^{-1}\right)$. Here, the flow discharge was calculated at $Q=20643 \mathrm{~m}^{3} \mathrm{~s}^{-1}$ (for a section $10 \mathrm{~m}$ high and
$235 \mathrm{~m}$ wide, and flow velocities of $14 \mathrm{~m} \mathrm{~s}^{-1}$ ). After the Jesus del Monte hill the flood was confined within the gully, along which several neighborhoods were located, including El Carmen village, which was dedicated to the "Maddona El Carmen", with an historical cemetery behind the church. The flood hit El Carmen village, which is located at $2.4 \mathrm{~km}$ from the flood source, at speeds of $7 \mathrm{~m} \mathrm{~s}^{-1}\left(25 \mathrm{~km} \mathrm{~h}^{-1}\right)$, knocking down the western walls of the church, while the entrance and altar were able to resist the impacts. The flow discharge calculated here was $Q=8722 \mathrm{~m}^{3} \mathrm{~s}^{-1}$ (for an area $10 \mathrm{~m}$ high by $150 \mathrm{~m}$ wide, and velocities of $10 \mathrm{~m} \mathrm{~s}^{-1}$ ).

The flood buried the church with $2.5 \mathrm{~m}$ of debris and mud. Behind the church, the flood was able to move and tilt grave markers as they are exposed nowadays. High-mud marks $5 \mathrm{~m}$ above the deposit that partially buried the church corroborated that the flood was moving as a hyperconcentrated flow. The flood was able to incorporated chunks of church walls as large as $30 \mathrm{~cm}$. Flow dynamics suggest that these blocks were suspended and rolled downstream.

Downstream and beyond this area, there are a lot of scattered remnants of the TFD deposit at several locations as far as $8 \mathrm{~km}$ downstream. In all these sections, the tailings deposit appears as a massive hyperconcentrated flow deposit without 
Table 4. Main input parameters used for the FLO-2D simulation.

\begin{tabular}{lrrrrrrrrr}
\hline Maximum flow discharge & \multicolumn{2}{c}{ viscosity } & \multicolumn{2}{c}{ yield stress } & \multicolumn{2}{c}{$\mathrm{Cv}$} & $n$ & $F$ \\
\hline & $\alpha$ & $\beta$ & $\alpha$ & $\beta$ & $\max$ & $\min$ & & \\
\hline $8000 \mathrm{~m}^{3} \mathrm{~s}^{-1}$ & 0.0648 & 6.2 & 0.0765 & 16.9 & 0.5 & 0.3 & 0.065 & 0.9 \\
\hline
\end{tabular}

Cv: sediment concentration; $n$ : Manning value; $F$ : limiting Froude number.

any signs of dilution into a sediment-laden flow. At section TL19 (one of the furthest sections from dam breakout) the flow had a discharge of $Q=2297 \mathrm{~m}^{3} \mathrm{~s}^{-1}$ (4 m high by $97 \mathrm{~m}$ wide) with flow velocities of $8.8 \mathrm{~m} \mathrm{~s}^{-1}$.

\subsection{Flow simulations}

The main Lamas flood that originated from the dam breaching is here simulated using the FLO-2D numerical code (O'Brien et al., 1993), a two-dimensional model that routes a bulked inflow hydrograph solving the dynamic-wave momentum equation in an unconfined channel (Fig. 15). The resistive component involves different shear stress (cohesive, viscous, turbulent, and dispersive) and the MohrCoulomb shear. The model was previously tested for different sediment-laden flows, such as debris flow (Sosio et al., 2007; Boniello et al., 2010; Hsu et al., 2010), lahars (Worni et al., 2012, Caballero et al., 2014), and debris flow from dam breach (Li et al., 2011). The quadratic rheological model requires two pairs of user-defined rheological coefficients $(\alpha$ and $\beta$ ) for viscosity and yields stress as a function of the sediment concentration by volume $(\mathrm{Cv})$. The input parameters also include the inflow hydrograph, the Manning $n$ value, the laminar flow resistance $(k)$, and the limiting Froude number (Table 4). To set up the input parameter field data, granulometric characteristics of the deposit (Table 4) and flow velocity estimations were used. The input parameters were back-calculated by a trial-and-error calibration on the flow thickness as observed in the field. The inflow hydrograph was constructed considering a sudden release of a water-saturated mass similar to a dam-breach event (Li et al., 2011) with a maximum flow discharge of $8000 \mathrm{~m}^{3} \mathrm{~s}^{-1}$, a value of 0.5 in sediment concentration $(\mathrm{Cv})$ at peak discharge, for a total outflow volume (sediment + water) of $2.5 \times 10^{6} \mathrm{~m}^{3}$, similar to the value estimated based on field evidences. The simulation was routed over a DEM of $10 \mathrm{~m}$ in resolution, the same value used for the computation grid. Maximum flow depths are reached in the proximal area. At Jesus del Monte church the flow profile indicates a maximum flow thickness of $14 \mathrm{~m}$ inundating the hill where the church is built. This discrepancy between the observed mud trace (Fig. 15a) and the simulated flow is mostly due to the resolution of the DEM, which is not able to exactly reproduce this topographic height. The same behavior is observed at the El Carmen church. Beside these differences, the overall maximum flow depth and distribution fit with the studied flow (Fig. 15b). Flow velocities were best reproduced for the El Carmen area, with maximum values up to $8 \mathrm{~m} \mathrm{~s}^{-1}$. In contrast, the highest velocities estimated for the proximal area $\left(22 \mathrm{~m} \mathrm{~s}^{-1}\right)$ were not reproduced by the model, probably because the initiation process of the dam breach behave more likely as a rapid landslide.

\section{Conclusions}

An extreme rainfall event, which lasted at least 5 days, triggered the softening and, ultimately, the breaching of the Los Cedros tailings dam at Tlalpujahua, central Mexico. Over 30 years the tailings dam accumulated $>2 \mathrm{Mt}$ of rock waste milled by cyanidation at Las Dos Estrellas mine. The sudden breaching of the dam generated a muddy flood that moved with a hyperconcentrated amount of sediments, destroying several settlements and a church, and killed circa 300 people. This study used historical photographic materials, eyewitness accounts, and data from recent field and laboratory studies to reconstruct the flood behavior with increasing distance from the source. We believe that our results provide a useful insight on such collapses. Worldwide databases of dam failures suggest that a combined effect of rainfall and dam rupture of the dam is the dominant cause of nearly $40 \%$ of all cases (Rico et al., 2008b). Thus, careful analyses of past catastrophic floods of tailings in inactive and active mining districts must be conducted to collect the knowledge analyzed and considered as basic knowledge to improve governmental regulations and oversight related to minimizing the risks of future hazardous events that may threaten human lives and property.

Author contributions. All authors carried out fieldwork at Tlalpujahua and participated during manuscript writing. P. Corona, M. Martínez, and V. H. Garduño revised the archive data of the mine and resumed local geology and mining activities. J. M. Sánchez analyzed grain size data, F. García performed granulometric analysis, L. Capra performed the flow simulations, and G. Cisneros managed the GIS database. J. L. Macías prepared the manuscript with contributions from all co-authors. 
Acknowledgements. We are grateful to the Museo Tecnológico y Minero del Siglo XIX "Dos Estrellas" for providing us unique oral information and access to its photographic archive of the disaster. We also thank Remedios Cisneros of the Instituto de Investigaciones Metalúrgicas, Universidad Michoacana de San Nicolas de Hidalgo, for the laser analyses of the fine-grained sample material. We appreciate the comments and suggestions made regarding this manuscript by Robert I. Tiling, the reviews of Pavel Raška and Fernando Nardi, and the editorial work of P. Tarolli.

Edited by: P. Tarolli

Reviewed by: Raška and F. Nardi

\section{References}

Albinson, T., Norman, D. I., Cole, D., and Chomiak, B. A.: Controls on formation of low-sulfidation epithermal deposits in Mexico: constraints from fluid inclusion and stable isotope data. Society of Economic Geologists Special Publication Series 8, 1-32, 2001.

Ayala-Carcedo, F. J.: La rotura de la balsa de residuos mineros de Aznalcóllar (España) de 1998 y el desastre ecológico consecuente del rio Guadiamar: causas, efectos y lecciones, Boletín Geológico y Minero, 115, 711-738, 2004.

Azam, S. and Li, Q.: Tailings Dam Failures: A Review of the Last One Hundred Years. Geotechnical News, December, 50-53, 2010.

Bernal-Navarro, G.: Notas y apuntes para la historia de la Mina Las Dos Estrellas. APE Editorial, México D.F., p. 80, 2012.

Berti, M., Genevois, R., and Tecca, P. R.: The 1985 flow slide and debris flow at Stava (Italy), in: Debris-Flow Hazards Mitigation, edited by: Chen, C.-L., American Society of Civil Engineers, New York, 309-321, 1997.

Blight, G. E.: Destructive mudflows as a consequence of tailings dyke failures, Proc. Inst. Civ. Eng. 125, 9-18, 1997.

Blight, G. E. and Fourie, A. B.: A review of catastrophic flow failures of deposits of mine waste and municipal refuse, Introductory report of the International Workshop on Occurrence and mechanisms of flows in natural slopes and earthfills, IWFLOWS2003, Sorrento, Italy, 14-16 May 2003, Associazione Geotecnica Italiana (AGI), available at: http://www.unina2.it/ flows2003/flows2003/articoli/articoli.htm, 2003.

Blight, G. E., Robinson, M. J. and Diering, J. A. C.: The flow of slurry from a breached tailing dam, Journal of South African Inst. Mining and Metallurgy, January, 1-8, 1981.

Boniello, M. A., Calligaris, C., Lapasin, R., and Zini, L.: Rheological investigation and simulation of a debris-flow event in the Fella watershed, Nat. Hazards Earth Syst. Sci., 10, 989-997, doi:10.5194/nhess-10-989-2010, 2010.

Caballero, L. and Capra, L.: The use of FLO2D numerical code in lahar hazard evaluation at Popocatépetl volcano: a 2001 lahar scenario, Nat. Hazards Earth Syst. Sci., 14, 3345-3355, doi:10.5194/nhess-14-3345-2014, 2014.

Centeno-García, E., Corona-Chávez, P., Talavera-Mendoza, O., and Iriondo, A.: Geology and tectonic evolution of the western guerrero terrane: a transect from Puerto Vallarta to Zihuatanejo. In: Geologic Transects Across Cordilleran Mexico, Guidebook for the fieldtrips of the 99th Geological Society of America Cordilleran Section Meeting 1-3 April, 2003 and Publicacion Especial del Instituto de Geología y Centro de Geociencias UNAM, México D.F., 201-228, 2003.

Chandler, R. J. and Tosatti, G.: The Stava tailings dam failure, Italy, July 1985, in: Proceedings of the Institution of Civil Engineers Geotechnical Engineering, 113, 67-79, 1995.

Comisión Nacional del Agua, available at: http://www.conagua. gob.mx/ (last access: 21 May 2015), 2013.

Corona Chávez, P., Uribe Salas, J. A., Razo Pérez, N., Martínez Medina, M., Maldonado Villanueva, R., Ramos Arroyo, Y. R., and Robles Camacho, J.: The impact of mining in the regional ecosystem: the mining district of El Oro and Tlalpujahua, Mexico, De Re Metallica, ISSN: 1577-903315, 2010 pp., 1-15, 2010.

De la Teja Segura, G.: Carta Geológico-Minera de Tlalpujahua. Secretaría de Comercio y Fomento Industrial, Chart and internal report p. 65, 2000.

Dobry, R. and Alvarez, L.: Seismic failures of Chilean tailings dams. Journal of the Soil Mechanics and Foundation Division, Ame. Soc. Civil Eng., 94, 237-260, 1967.

East, D. R.: Tailings dam failures - why do they continue to occur?, Mining Engineering, 2, 57-60, 2000.

Flores, T.: Estudio geológico-minero de los distritos de El Oro y Tlalpujahua, Boletín del Instituto Geológico de México, Núm. 37, México, 1920.

Folk, R. L. and Ward, W. C.: Brazos river bar: a study of significance of grain size parameters, J. Sediment. Petrol., 27, 3-26, 1957.

Genevois, R. and Tecca, P. R.: The tailings dams of Stava (northern Italy): An analysis of the disaster, in: Environmental Management, edited by: Chowdhury, R. and Sivakumar, M., GeoWater and Engineering Aspects. A.A. Balkema, Rotterdam, 23$38,1993$.

Gens, A. and Alonso, E. E.: Aznalcóllar dam failure. Part 2: Stability conditions and failure mechanism, Géotechnique, 56, 185201, 2006.

Gipson, A. H.: Tailings dam failures — the human factor. In: Tailings and Mine Waste '03, Balkema Publishers, Lisse, A.A. 451456, 2003.

Gómez-Tuena, A., Orozco-Esquivel, M. T., and Ferrari, L.: Igneous petrogenesis of the Trans-Mexican Volcanic Belt, in: Geology of México: Celebrating the Centenary of the Geological Society of México, edited by: Alaníz-Álvarez, S. A. and Nieto-Samaniego, Á. F., Geological Society of America Special Paper 422, 129181, 2007.

Hsu, S. M., Chiou, L. B., Lin, G. F., Chao, C. H., Wen, H. Y., and $\mathrm{Ku}, \mathrm{C}$. Y.: Applications of simulation technique on debris-flow hazard zone delineation: a case study in Hualien County, Taiwan, Nat. Hazards Earth Syst. Sci., 10, 535-545, doi:10.5194/nhess10-535-2010, 2010.

INEGI: Instituto Nacional de Estadística, Geografía e Informática, 1:50 000 digital mapping, 2007.

Inman, D. L.: Measures of describing the size distribution of sediments, J. Sediment. Petrol., 22, 125-145, 1952.

Juárez Bobadilla J. A.: Las Lamas. 27 de mayo 1937. El Despertador Tlalpuhahuense, available at: http://tlalpujahua.blogspot.mx/ 2007/06/las-lamas-27-de-mayo-1937.html (last access: 21 May 2015), 2007.

Kellerhals, R. and Bray, D.: Sampling procedures for coarse fluvial sediments, J. Hidraul. Div., 97, 1165-1180, 1971. 
Klohn, W.: Hidrografía de las zonas desérticas de Chile. Contribución Proyecto CHI-35. Programa de las Naciones Unidas para el Desarrollo, p. 188, 1972.

Li, M. H., Sung, R. T., Dong, J. J. Lee, C. T., and Chien-Chih Chen, C. C.: The formation and breaching of a short-lived landslide dam at Hsiaolin Village, Taiwan - Part II: Simulation of debris flow with landslide dam breach, Eng. Geol., 123, 60-71, 2011.

Maldonado Villanueva. R.: Caracterización mineralógica de fases minerales metálicas en muestras de jales del distrito minero El Oro-Tlalpujahua, México. Universidad Nacional Autónoma de México, Facultad de Ingeniería, Tesis de licenciatura, 89 pp., 2008.

Martínez Medina, M., Corona Chávez, P., Ramos Arroyo, Y., Bocco Verdinelli, G., and Martínez Arredondo, J. C.: Caracterización hidrográfica del distrito minero el oro y tlalpujahua: implicaciones en los procesos de erosión y de remoción de los residuos mineros, Simposio de la cuenca del lago de Cuitzeo, Morelia Mich, 14-16 November, Memorias, 35-42, 2012.

Neves Correia dos Santos, R., Maria Mello Saraiva Caldeira, L., and Bilé Serra, J. P.: FMEA of a tailings dam, Georisk, Assess. Manag. Risk Eng. Syst. Geohazards, 6, 1-16, doi:10.1080/17499518.2011.615751, 2011.

Nieto Monroy, A. P.: Variabilidad espacial y temporal de la hidrogeoquímica de arroyos del Distrito Minero El Oro-Tlalpujahua, Guanajuato: Universidad de Guanajuato, Tesis de Licenciatura, p. 64, 2007.

Van Nierkirk, H. J. and Viljoen, M. J.: Causes and consequences of the Merriespruit and other tailings-dam failures, Land Deg. Develop., 16, 201-212, 2005.

O'Brien, J., Julien, P., and Fullerton, W.: Two-dimensional water flood and mudflow simulation, J. Hydraul. Eng.-ASCE, 119, 244-261, 1993.

Ostroumov, M., and Corona-Chávez, P.: Ensayo metalogenético del estado de Michoacán. in: La Carta Geológica del Estado de Michoacán escala 1: 250000 en 4 hojas con notas explicativas, p. 27, 1999.

Reiniery, E.: Aceituno, Informe geológico de la región auroargentífera de El Oro, México, y Tlalpujahua, Michoacán, México, s/e. Consejo de Recursos Minerales, p. 56, 1955.

Rico, M., Benito, G., and Díez-Herrero, A.: Floods from tailings dam failures, J. Hazardous Mater., 154, 79-87, 2008a.
Rico, M., Benito, G., Salgueiro, A. R., Diez-Herrero, A., and Pereira, H. G.: A review of the European incidents in the worldwide context Reported tailings dam failures, J. Hazardous Mater., $152,846-852,2008 b$.

Sammarco, O.: A tragic disaster caused by the failure of tailings dams leads to the formation of the Stava 1985 Foundation, Mine Water Environ., 23, 91-95, 2004.

Sheridan, M. F., Stinton, A. J., Patra, A., Pitman, E. B., Bauer, B., and Nichita, C. C.: Evaluating Titan2D mass-flow model using the 1963 Little Tahoma Peak avalanches, Mount Rainier, Washington, J. Volcanol. Geotherm. Res., 139, 89-102, 2005.

Siebe, C. D., Jahn, R., and Stahr, K.: Manual para la Descripción y Evaluación Ecológica de Suelos en el Campo: Chapingo, México. Sociedad Mexicana de la Ciencia del Suelo, A.C., Publicación Especial, 4, 57 pp., 1996.

Silva Ortiz, I. and Salgado Soto, Z.: Estudio estratigráfico estructural en la región de Tlalpujahua- El Oro, Edos de Mich. Méx. Ed. Instituto Politécnico Nacional. México D.F., 74 pp., 1988.

Sosio, R., Crosta, G. B., and Frattini, P.: Field observations, rheological testing and numerical modelling of a debris-flow event, Earth Surf. Process. Landf., 32, 290-306, 2007.

Uribe Salas, J. A.: Recuento histórico bibliográfico de la minería en la región central de México. Ed. UMSNH, IIH y Departamento de Historia de México, 271 pp., 1994.

Uribe Salas, J. A.: Historia de la mineria en Michoacán, volumen II. Ed. UMSNH, Sociedad Mexicana de Mineralogía, Museo Tecnológico del Siglo XIX “Las Dos Estrellas”, 2 vols. Morevallado Editores, Morelia, Michoacán, p. 227, 2008.

Uribe Salas, J. A.: Historia económica y social de la Compañía Minera "Las Dos Estrellas" en El Oro y Tlalpujahua, 18981959. México, Universidad Autónoma Metropolitana, Universidad Michoacana de San Nicolás de Hidalgo. Morevallado Editores, Morelia, Michoacán, p. 560, 2009.

Uribe Salas, J. A.: Notas y apuntes para la historia de la Mina Las Dos Estrellas (1899-1960). Museo Tecnológico Mineo del Siglo XIX. APE Editorial, México D.F., p. 80, 2012.

US National Committee on Large Tailings Dams: Tailings dam incidents, 1994.

Worni, R., Huggel, C., Stoffel, M., and Pulgarín, B.: Challenges of modeling current very large lahars at Nevado del Huila Volcano, Colombia, Bull. Volcanol., 74, 309-324, 2012. 